\title{
A dock derived compound against laminin receptor ( 37 LR) exhibits anti-cancer properties in a prostate cancer cell line model
}

\author{
Charles Samuel Umbaugh ${ }^{1}$, Adriana Diaz-Quiñones ${ }^{1}$, Manoel Figueiredo Neto ${ }^{1}$, \\ Joseph J. Shearer ${ }^{1}$ and Marxa L. Figueiredo ${ }^{1}$ \\ ${ }^{1}$ Department of Basic Medical Sciences, Purdue University College of Veterinary Medicine, West Lafayette, IN 47907, USA \\ Correspondence to: Marxa L. Figueiredo, email: mlfiguei@purdue.edu
}

Keywords: laminin receptor, drug discovery, prostate cancer, anti-cancer compound

Received: April 13, $2017 \quad$ Accepted: July 16, $2017 \quad$ Published: December 13, 2017

Copyright: Umbaugh et al. This is an open-access article distributed under the terms of the Creative Commons Attribution License 3.0 (CC BY 3.0), which permits unrestricted use, distribution, and reproduction in any medium, provided the original author and source are credited.

\section{ABSTRACT}

Laminin receptor ( $67 \mathrm{LR}$ ) is a $67 \mathrm{kDa}$ protein derived from a $37 \mathrm{kDa}$ precursor (37 LR). 37/67 LR is a strong clinical correlate for progression, aggression, and chemotherapeutic relapse of several cancers including breast, prostate, and colon. The ability of $37 / 67$ LR to promote cancer cell aggressiveness is further increased by its ability to transduce physiochemical and mechanosensing signals in endothelial cells and modulate angiogenesis. Recently, it was demonstrated that 37/67 LR modulates the anti-angiogenic potential of the secreted glycoprotein pigment epithelium-derived factor (PEDF). Restoration of PEDF balance is a desirable therapeutic outcome, and we sought to identify a small molecule that could recapitulate known signaling properties of PEDF but without the additional complications of peptide formulation or gene delivery safety validation. We used an in silico drug discovery approach to target the interaction interface between PEDF and 37 LR. Following cell based counter screening and binding validation, we characterized a hit compound's antiviability, activation of PEDF signaling-related genes, anti-wound healing, and anticancer signaling properties. This hit compound has potential for future development as a lead compound for treating tumor growth and inhibiting angiogenesis.

\section{INTRODUCTION}

Laminin receptor $(67 \mathrm{LR})$ is a $67 \mathrm{kDa}$ protein derived from a $37 \mathrm{kDa}$ precursor protein (37 LR) [1-3]. The derivation process most likely involves posttranslational modification of 37 LR by acylation [3] or other lysine-directed conjugations $[4,5]$. Because the two species are interrelated, laminin receptor at large is referred to as $37 / 67 \mathrm{LR}$. $37 / 67 \mathrm{LR}$ is a member of the non-integrin receptor family [2]. $37 \mathrm{LR}$ is encoded by the gene RPSA $[6,7]$, facilitates ribosome assembly [8], and is distributed to nuclear and cytoplasmic compartments of the cell [9]. Using laminin sepharose columns and/or tumor cells, several groups isolated and identified 67 LR [10-12]. $37 / 67 \mathrm{LR}$, perhaps owing to its laminin binding capacity, is frequently found at the plasma membrane [13-16]. Both 37 LR and $67 \mathrm{LR}$ are able to bind laminin and laminin derived peptides $[17,18]$, molecules intimately involved in normal cell to matrix contact [19] and pathologically associated with cancer progression, metastasis, and invasion [20].

$37 / 67$ LR is regarded as a strong clinical correlate for progression, aggression, and chemotherapeutic relapse of several cancers including breast, prostate, and colon $[21,22]$. The C-terminus of 37/67 LR has been suggested to increase viability and enhance survival of breast cancer cells [23]. In a lung cancer model, endogenous 37 LR expression levels were correlated with metastatic status, and overexpression of 37 LR enabled lung cancer cells to establish lung metastases in vivo [24]. Upregulation of $67 \mathrm{LR}$ also has been associated with melanocyte tumor development [25], and invasiveness of ovarian and endometrial cancer [26, 27]. Downregulation of 37/67 LR by RNA interference (RNAi) inhibits cell migration and invasiveness [28], reduces cell binding to laminin and enhances the apoptotic response of colon cancer cells to doxorubicin [29], and inhibits hepatoma cell viability [30]. 
The ability of $37 / 67$ LR to promote cancer cell aggressiveness is further increased by the ability of 37/67 LR to transduce physiochemical and mechanosensing signals in endothelial cells [31] and modulate angiogenesis [32] - a key component of the tumor/microenvironment interaction [33]. Recently, it was demonstrated that 37/67 LR modulates the anti-angiogenic potential of the secreted glycoprotein pigment epithelium-derived factor (PEDF) [34]. Originally discovered as a regulator of retinal and ocular health [35-37], PEDF is a non-inhibitory member of the serine protease inhibitor family that has been regarded as a novel and potent inhibitor of angiogenesis [38]. Administration or expression of full length PEDF or peptides derived from PEDF [39] markedly reduces vascularization [40] and endothelial cell viability [41] concomitant with a decrease in endogenous vascular endothelial growth factor (VEGF) [42].

Outside of angiogenic models, imbalance of endogenous PEDF has been observed in many cancers [43-45]. Restoration of PEDF balance is a desirable therapeutic outcome and has been achieved largely via gene delivery regimens [46-50] or through administration of PEDF peptides [39]. Additionally, 37/67 LR has been identified as an emerging and promising target for pharmacological intervention in cancer progression [51]. Therapeutic targeting to $37 / 67$ LR has focused on the interaction between 37/67 LR and the green tea natural product, epigallocatechin gallate (EGCG) [52-54]. Acting through 37/67 LR, EGCG elicits anti-proliferative and anti-cancer effects in several cell lines [55-59]. Of high relevance to our study, a recent virtual based screen of National Cancer Institute (NCI) compounds against the laminin binding domain of 37/67 LR isolated several active chemicals with the ability to inhibit cell migration and binding to laminin at low micromolar doses [60].

Here, we used an in silico drug discovery approach to target the interaction interface between PEDF and 37 LR. Following cell based counter screening and binding validation, we characterized a hit compound's antiviability, activation of PEDF signaling-related genes, antiwound healing, and anti-cancer signaling properties. This hit compound has potential for future development as a lead compound for treating tumor growth and inhibiting angiogenesis.

\section{RESULTS}

\section{In silico screens produced a hit compound with promising antitumor activity in in vitro assays}

Docking the Maybridge Hitfinder ${ }^{\mathrm{TM}}$ library against the 37 LR crystal structure using "Docking @ UTMB" generated 24 compounds with predicted docking scores ranging from $-9.3 \mathrm{kcal} / \mathrm{mol}$ to $-7.9 \mathrm{kcal} / \mathrm{mol}$. After excluding compounds with poor chemical qualities, seven compounds were chosen for further in vitro studies. Notably, all compounds contained piperazine-like moieties (Figure 1) and had little to no preexisting data in the chemical literature. We carried out a 96 hour study of cell viability for the initial compound screen because we did not know the relationship between time and dose for the compounds selected a priori. A six-dose screen $(6 \mu \mathrm{M}$ to $100 \mu \mathrm{M})$ (Figure 2) separated compounds into two groups. $\mathrm{C} 1, \mathrm{C} 2, \mathrm{C} 3$, and $\mathrm{C} 4$ inhibited cell viability in a dose dependent manner whereas C5, C6, and C7 had mixed responses or did not inhibit cell viability in various cell lines. The vehicle, DMSO, had no effect on tumor cell lines LNCaP, TC2-Ras, PC-3, or SH-SY5Y but did have a mild effect on Ea.hy.926 endothelial cells at higher doses. $\mathrm{IC}_{50} \mathrm{~s}$ obtained from dose response curves revealed that $\mathrm{C} 3$ had the strongest effect on cell viability in the majority of cell lines tested. C3 inhibited cell viability in the androgen dependent LNCaP cell line $(10.28 \mu \mathrm{M})$, the aggressive and metastatic androgen independent $\mathrm{PC}-3$ cell line $(\sim 0.8 \mu \mathrm{M})$, and in the neuroblastoma cell line SH-SY5Y (18.57 $\mu \mathrm{M})$ (Table 1). Because C3 strongly inhibited cell viability in PC-3 cells, we chose to investigate the mechanism for reduction of cell viability using these cells.

\section{Effectiveness Of $\mathrm{C} 3$ correlates with endogenous 37 LR levels}

Because C3 reduced cell viability at lower concentrations in PC-3 and LNCaP cell lines than TC2Ras, SH-SY5Y, and Ea.hy.926 cell lines, we examined whether $\mathrm{C} 3 \mathrm{IC}_{50}$ values might correlate with endogenous 37 LR levels. PC-3 and LNCaP cell lines expressed 37 LR approximately two fold higher than SH-SY5Y and 1.5 fold higher than Ea.hy.926 and TC2-Ras, with a modest correlation $\left(r^{2}=0.6\right)$ between lower $\mathrm{C} 3 \mathrm{IC}_{50} \mathrm{~s}$ and higher expression levels of 37 LR (Supplementary Figure 1).

\section{Redocking of hit compound C3}

C3 was redocked to the 37 LR crystal structure using AutoDock Vina and AutoDockTools to assess predicted binding state and visualized using PyMol. Using a grid encompassing the entire protein as described in the methods, C3 was predicted to interact with His-169 of the 37 LR structure via a $3.3 \AA$ hydrogen bond (Figure 3 ). Moreover, the predicted interaction site lies within the first binding region for laminin and the known binding region for PEDF. Altering the protonation state of His169 did not change predicted binding of C3 in simulation (Supplementary Figure 2).

\section{$\mathrm{C} 3$ reduces intrinsic tryptophan fluorescence in peptide $\mathbf{G}-\mathbf{A}$ peptide representing the 37 LR laminin binding pocket}

Computational redocking suggested that C3 engaged $37 \mathrm{LR}$ at His 169, a residue that lies squarely within the laminin binding region of 37 LR and notably, the active 
laminin binding site spanning amino acids 161 to 180 [61]. After inspecting the amino acid sequence, commonly referred to as Peptide G, we noticed that the sequence contained two tryptophans. We tested the hypothesis that alterations to intrinsic tryptophan fluorescence could be a readout for $\mathrm{C} 3$ binding to Peptide $\mathrm{G}$ by titrating $\mathrm{C} 3$ in an assay buffer containing Peptide G or a 20-mer same sequence scramble (Scramble G) (Figure 4). Titration of C3 from 0.1 to $100 \mu \mathrm{M}$ reduced intrinsic tryptophan fluorescence in a dose dependent manner with an EC50 of $16.1 \mu \mathrm{M}$. Titration of C3 did not appreciably alter the intrinsic tryptophan fluorescence of Scramble G.

\section{C3 treatment elicits PEDF-like gene expression changes in PC-3 cells}

Since C3 inhibited cell viability and displayed predicted binding to empirically determined binding sites on 37 LR [34], we used RT-qPCR to screen a panel of known PEDF-signaling related genes involved in PEDF's ability to both inhibit angiogenesis and activate apoptosis in a cell-type dependent manner (Figure 5A). mRNA levels were examined at 48 hours to provide a window for newly synthesized transcripts to be measured. Genes involved in migration/invasion and/or extracellular matrix (ECM) communication also were assayed. We observed significant $(p<0.05)$ upregulations in vascular endothelial growth factor (VEGF), thrombospondin-1 (THBS1), matrix metalloproteinase (MMP)-2 and -9, and downregulations in vascular endothelial growth factor receptor 2 (VEGFR2). Transforming growth factor beta (TGFB) and tissue inhibitor of metalloproteinase 2 (TIMP2) were downregulated and proapoptotic factors caspase-3 (CASP3) and bcl-2-associated x protein (BAX) and migration/invasion regulators Rho guanine nucleotide exchange factor 7 (PIXB) and PAK1 (P21 (RAC1) Activated Kinase 1) were upregulated as a trend, but these changes were not significant.

\section{C3 inhibits endothelial tube formation}

Because C3 downregulated VEGFR2 and upregulated THBS1 in PC3 cells, we tested the hypothesis that $\mathrm{C} 3$ exhibited anti-angiogenic potential using an endothelial tube formation assay (Figure 5B). In this assay, tube formation proceeded uninhibited by the

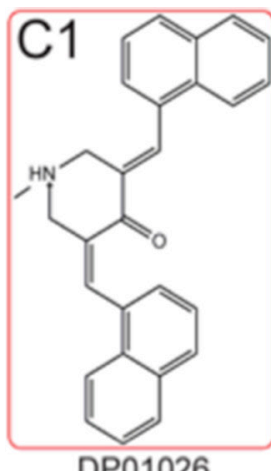

DP01026

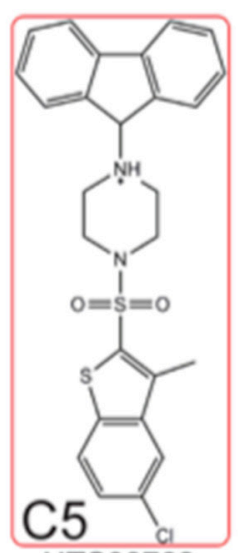

HTS08762

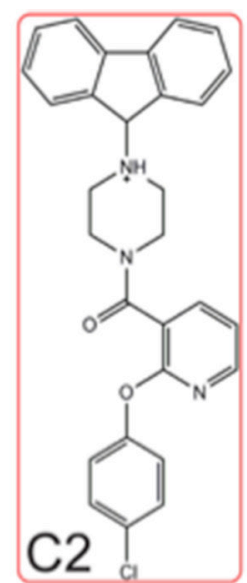

HTS07938

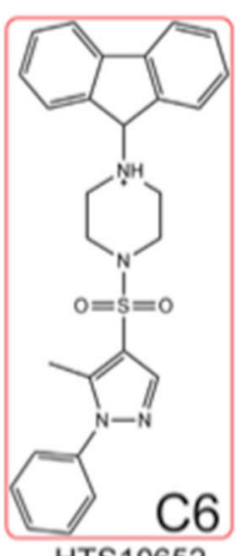

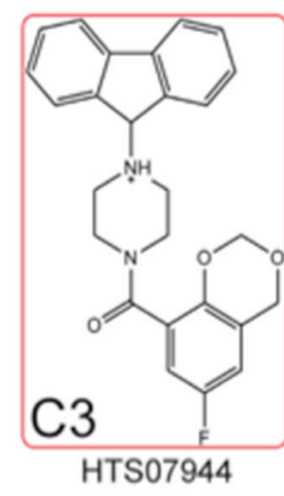
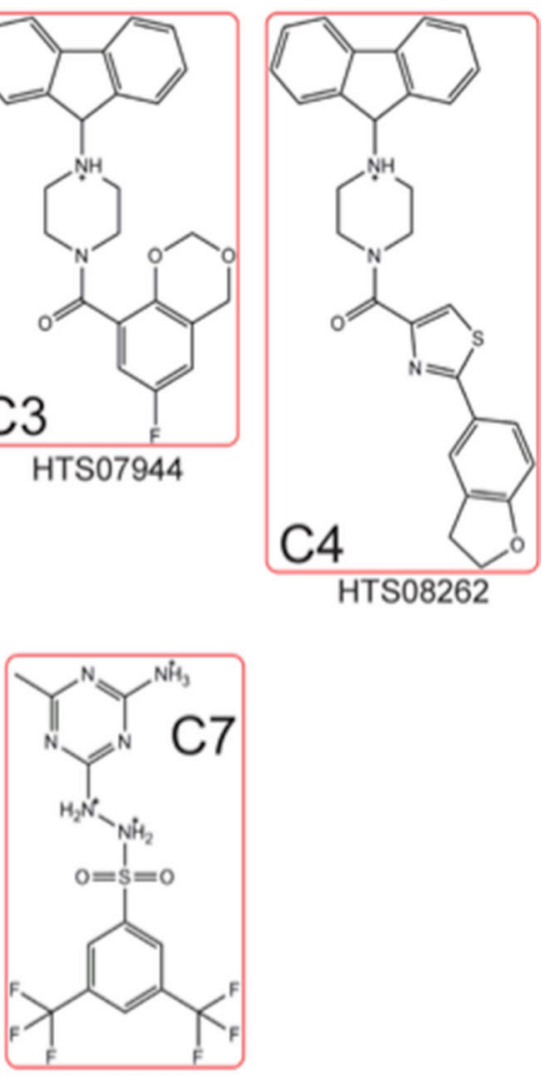

RF02945

HTS10652

Figure 1: Dock derived compounds tested via in vitro screen. Dock derived compounds depicted with nicknames (C\#) and Maybridge HitFinderTM designations. Structures were generated using ChemDraw. 
Table 1: Tabulated cell viability $\mathrm{IC}_{50 \mathrm{~s}}$

\begin{tabular}{cccccc}
\hline 96 Hour IC $\mathbf{I 0}_{\mathbf{5 0}}(\boldsymbol{\mu M})$ & Endo & LNCaP & TC2-Ras & PC3 & SH-SY5Y \\
\hline C1 & 12.54 & 31.79 & $\sim 29.12$ & 25.22 & 22.19 \\
$\mathbf{C 2}$ & 23.44 & 15.65 & 24.61 & 16.52 & 25.87 \\
$\mathbf{C 3}$ & 23.10 & 10.28 & $\sim 31.38$ & $\sim 0.7577$ & 18.57 \\
$\mathbf{C 4}$ & 22.12 & 12.35 & $\sim 5.073$ & $\sim 29.15$ & $\sim 31.93$ \\
$\mathbf{C 5}$ & 47.01 & 14.84 & $\sim 671.5$ & $\sim 58.42$ & $\sim 22.94$ \\
$\mathbf{C 6}$ & 47.01 & $\sim 56.36$ & $\sim 782.7$ & $\sim 51.66$ & $\sim 124.0$ \\
$\mathbf{C 7}$ & 47.01 & 159.6 & - & 43.06 & 82.24 \\
\hline
\end{tabular}

presence of vehicle (DMSO), but not in the presence of 1,10 , or $50 \mu \mathrm{M}$ of $\mathrm{C} 3$ compound $(p<0.05)$. Inhibition of tube formation by $\mathrm{C} 3 \mathrm{did}$ not alter calcein uptake (data not shown), suggesting the inhibition was not driven by a direct apoptotic mechanism.

\section{C3 does not inhibit cell viability via Caspase 3/7 mediated apoptosis}

To determine the mechanism for inhibition of cell viability by $\mathrm{C} 3$, we treated $\mathrm{PC}-3$ cells with 1,10 , or $50 \mu \mathrm{M}$ of $\mathrm{C} 3$ for $6,12,24$, or 48 hours continuously and measured activation of caspase 3/7 using a luminescence based assay (Figure 6A). At 6 hours, $50 \mu \mathrm{M} \mathrm{C} 3$ caused a slight increase in caspase $3 / 7$ activity but the results were not significant at any time point for any dose.

\section{C3 inhibits cell viability via inhibition of cellular proliferation}

Since $\mathrm{C} 3$ did not appear to inhibit cell viability by an apoptotic mechanism, we tested the hypothesis that PC-3 cells inhibited cell viability due to a reduction in cellular proliferation in response to treatment. A dose curve for C3 was established and bromodeoxyuridine (BrdU) incorporation was used as a readout for proliferation (Figure 6B). We observed inhibition of BrdU incorporation in a dose dependent manner after treatment for 24 hours with an $\mathrm{IC}_{50}$ of $10.08 \mu \mathrm{M}$.

\section{Label-free quantitative proteomics suggests C3 alters levels of proteins associated with DNA maintenance, DNA synthesis, and protein translation}

To further elucidate potential mechanisms of action for $\mathrm{C} 3$, we employed a label free quantitative mass spectrometry approach. Differential changes to the proteome of PC-3 cells were examined at 72 hours to provide a viable window for newly translated proteins to be measured. Perseus was used to generate a volcano plot of significantly up and down regulated proteins from the 3,904 proteins differentially detected between vehicle control (DMSO) and $10 \mu \mathrm{M} \mathrm{C} 3$ after 72 hours of treatment. 29 proteins were significantly differentially regulated in response to $\mathrm{C} 3$ treatment (Figure 7) and 16 proteins were significantly differentially regulated at a fold change cutoff of 1.5 (Table 2). Specific protein changes induced by $\mathrm{C} 3$ treatment included downregulation of the mini chromosome maintenance (MCM) family of proteins, responsible for replication fork formation. C3 also downregulated two E2 ubiquitin ligases required for mitotic progression (UBE2C and UBE2S). The most downregulated protein $(-5.3 \mathrm{FC}), \mathrm{RPL} 29$, is incorporated into the $60 \mathrm{~S}$ ribosome. Additionally, the second most upregulated protein (1.9 FC), ICT1, responds to stalled mitochondrial ribosomes.

\section{Ingenuity pathway analysis predicts inactivation of Myc, activation of P53, and suggests a doxorubicin like phenotype}

Proteomics analyses utilizing Ingenuity Pathway Analysis (IPA) of significant ( $p<0.05, \mathrm{FC} 1.5$ ) proteins altered upon treatment with $10 \mu \mathrm{M}$ of compound $\mathrm{C} 3$ suggested a predicted activation of tumor suppressor p53 pathways and a predicted deactivation of tumor promoter c-myc (Figure 8). IPA predicted an activation of P53 corresponding to the experimentally detected downregulations of MCM family proteins and other proteins involved in DNA synthesis and integrity (KPNA2, UBE2C, WDHD1). IPA predicted an inactivation of c-myc corresponding to downregulation of MCM6, UBE2C, and UBE2S and the upregulation of ASNS (asparagine synthase). The proteomic signature obtained with $\mathrm{C} 3$ compared to vehicle control (DMSO) was linked to the well-characterized chemotherapeutic doxorubicin by IPA.

\section{$\mathrm{C} 3$ inhibits c-Myc binding activity at $50 \mu \mathrm{M}$}

Because P53 status and function is impaired in PC-3 cells, we chose to orthogonally validate the IPA prediction of c-myc inactivation using a promoter-based reporter assay (Figure 9) consisting of four c-myc binding sites upstream of a luciferase gene [62]. 1 and $10 \mu \mathrm{M} \mathrm{C} 3$ had no significant effect on luciferase reporter activity however $50 \mu \mathrm{M} \mathrm{C} 3$ significantly reduced c-myc binding activity by $36 \%$. 
C1

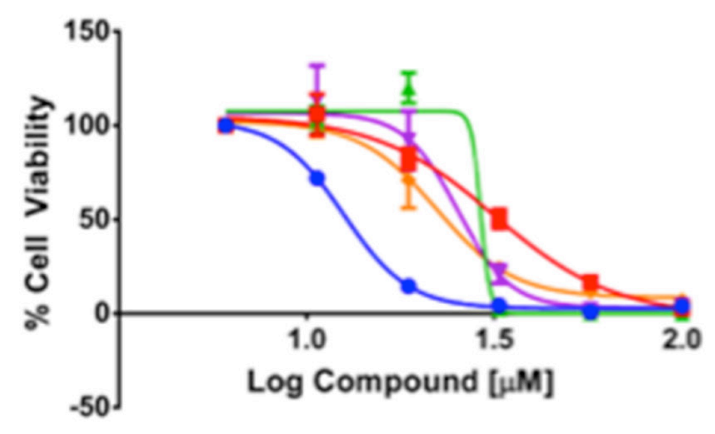

C3

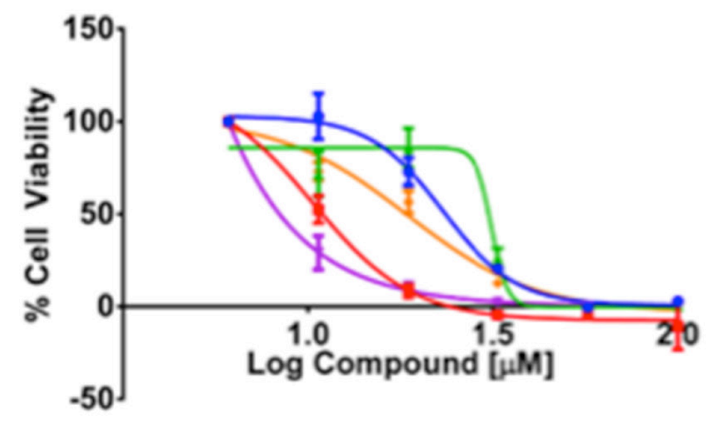

C5

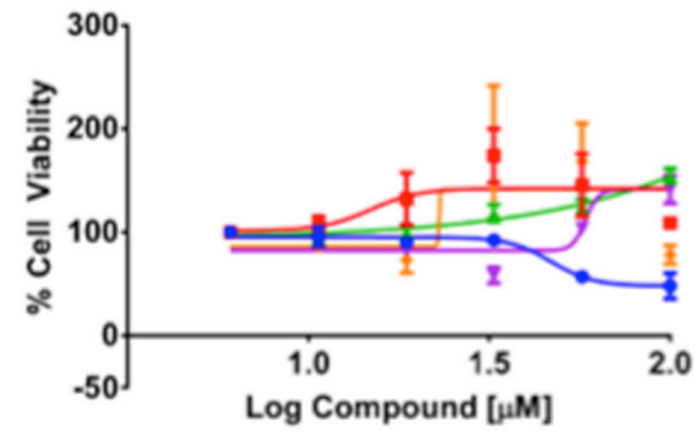

C7

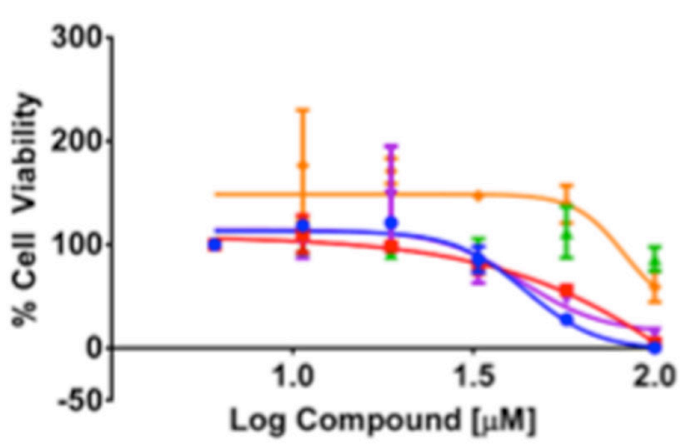

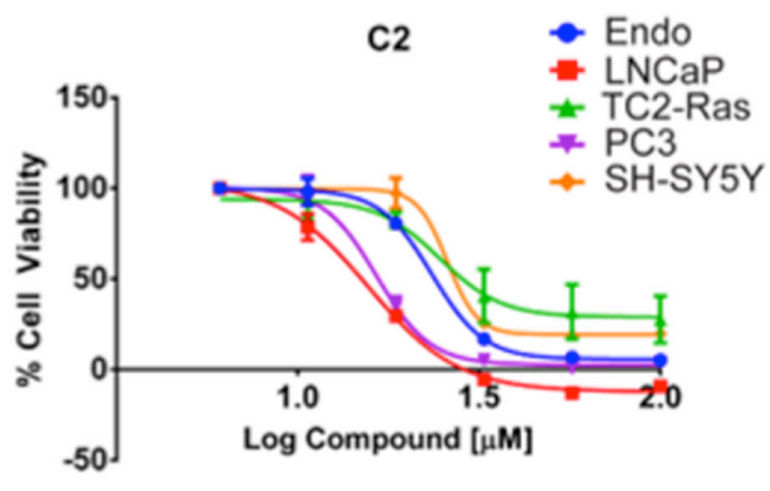

C4

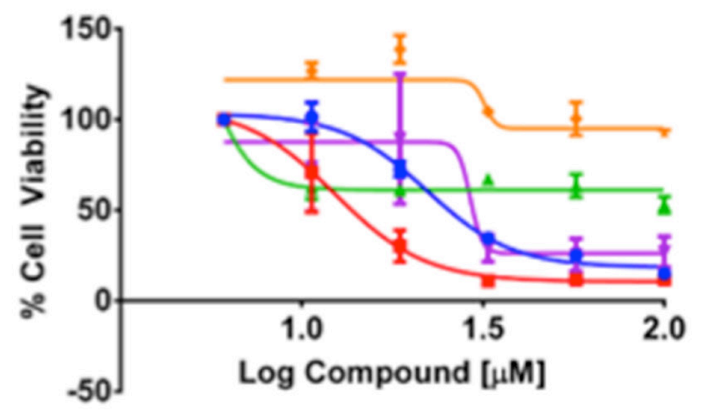

C6

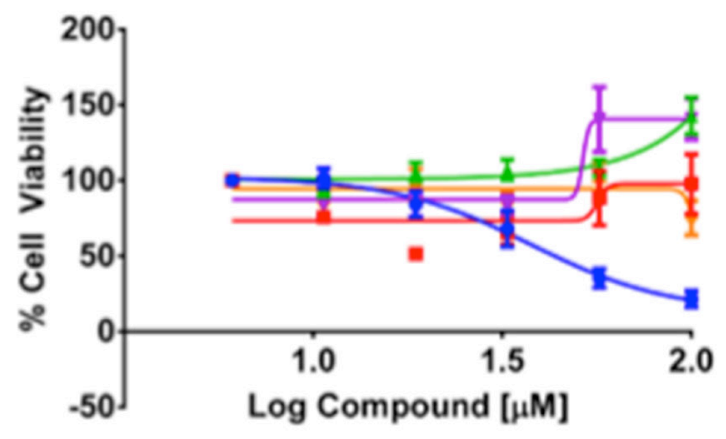

DMSO

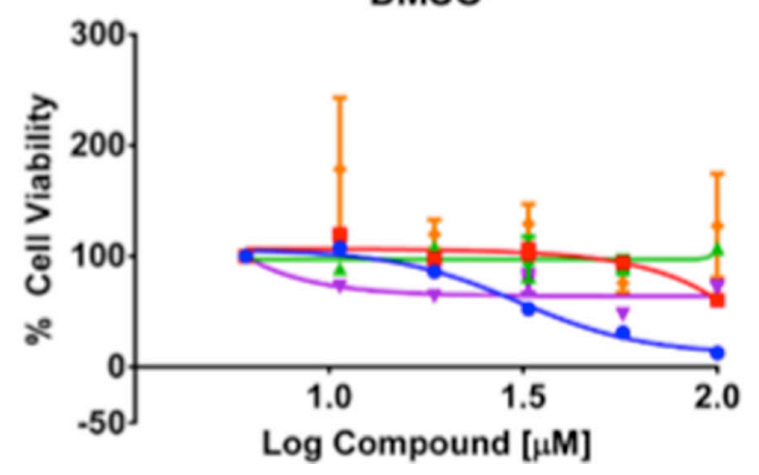

Figure 2: Dose response curves. Dose response curves for cell lines treated with $6,10.5,18.6,32.4,57.5$, and $100 \mu \mathrm{M}$ of compound ( $\log$ ) for 96 hours using \% cell viability derived from CCK-8 absorbance readings at $450 \mathrm{~nm}(n=3$, mean \pm SEM). A DMSO equivalent control ( $n=2 \pm \mathrm{SEM}$ ) was also included for each cell line tested: Ea.hy.926 endothelial cells (Endo), LNCaP androgen dependent metastatic prostate cancer cells, TC2-Ras mouse prostate cancer cells, PC-3 androgen independent metastatic prostate cancer cells, and SH-SY5Y neuroblastoma cells. Curves were fit using GraphPad Prism as described in the methods. 
Table 2: Significantly up and down regulated proteins in response to $10 \mu \mathrm{M} \mathrm{C3}$

\begin{tabular}{|c|c|c|c|}
\hline Gene & Uniprot Accession & Protein Name & $\log _{2}(\mathrm{FC})$ \\
\hline MMGT1 & Q8N4V1 & Membrane magnesium transporter 1 & 3.1 \\
\hline ICT1 & Q14197 & Peptidyl-tRNA hydrolase ICT1, mitochondrial & 1.9 \\
\hline FTH1 & P02794 & Ferritin heavy chain & 1.8 \\
\hline ASNS & P08243 & Asparagine synthetase & 1.5 \\
\hline$G P X 1$ & P07203 & Glutathione peroxidase 1 & 1.5 \\
\hline МСM6 & Q14566 & Minichromosome maintenance protein 6 & -1.5 \\
\hline МСM4 & P33991 & Minichromosome maintenance protein 4 & -1.5 \\
\hline MCM3 & P25205 & Minichromosome maintenance protein 3 & -1.6 \\
\hline NUFIP2 & Q7Z417 & Nuclear fragile $\mathrm{X}$ mental retardation-interacting protein 2 & -1.7 \\
\hline NT5DC1 & Q5TFE4 & 5'-nucleotidase domain-containing protein 1 & -2.1 \\
\hline$C D A$ & P 32320 & Cytidine deaminase & -2.3 \\
\hline KPNA2 & P52292 & Importin subunit alpha-1 & -2.3 \\
\hline UBE2S & Q16763 & Ubiquitin-conjugating enzyme E2 S & -2.7 \\
\hline WDHD1 & O75717 & WD repeat and HMG-box DNA-binding protein 1 & -3.2 \\
\hline$U B E 2 C$ & O00762 & Ubiquitin-conjugating enzyme $\mathrm{E} 2 \mathrm{C}$ & -3.2 \\
\hline RPL29 & P47914 & 60 S ribosomal protein L29 & -5.2 \\
\hline
\end{tabular}

\section{Compound $\mathrm{C} 3$ inhibits wound healing in a scratch assay using $\mathrm{PC} 3$ cells}

Because $\mathrm{C} 3$ inhibited growth pathways in several different assays, we decided to investigate whether $\mathrm{C} 3$ could inhibit wound healing in a scratch test assay as a measure of cancer cell aggressiveness as it relates to their migration capacity. The scratch assay is a well-developed method for measuring cell migration in vitro and was chosen because it mimics cell migration during wound healing in vivo and is compatible with live cell imaging [63]. In this assay, we utilized the t-scratch method to assess the ability of compound $\mathrm{C} 3$ to promote wound closure or healing. PC3 cells were treated for $48 \mathrm{~h}$ with vehicle control (DMSO), or 1, 10, or $50 \mu \mathrm{M}$ compound $\mathrm{C} 3$. A t-scratch was made in the center of the wells and imaged over time using a brightfield microscope (Figure 10A). Quantification of the wound closure was performed as described in materials and methods using tscratch software. We observed that compound $\mathrm{C} 3$ prevented wound closure by $\sim 70 \%$ at $50 \mathrm{uM}$ ( $p<0.05$; Figure 10B).

\section{DISCUSSION}

We have demonstrated that phenotypic cell survival assays can be effectively coupled to virtual based screening methods to identify novel compounds that alter and inhibit castration resistant prostate cancer cell (PC-3) growth in the context of the PEDF/LR interaction interface. It has been shown that in silico approaches to drug discovery are a useful tool for cancer biologists and facilitate hypothesis driven research avenues without the expensive startup costs associated with biochemical drug discovery that may be underutilized on compounds that do not display desirable anti-tumor properties in downstream in vitro and in vivo functional assays [64]. Moreover, in silico approaches are becoming more accessible [65] and user friendly and the datasets generated can be explored and readily refined with input from expert medicinal chemists.

HTS07944, or C3, was able to inhibit cell viability at $\sim 1 \mu \mathrm{M}$ and inhibited cellular proliferation at $10 \mu \mathrm{M}$ in PC3 cells. Additionally, a $50 \mu \mathrm{M}$ dose was sufficient to inhibit cell migration in a wound healing assay. Taken together, $\mathrm{C} 3$ had a clear effect on PC-3 cell viability and function. $\mathrm{C} 3$ is a piperazine analogue, a class of compounds well characterized for their diverse uses in medicinal chemistry ranging from neuropsychiatric applications [66], tuberculosis treatment [67], anti-angiogenic therapy [68], to cancer [69]. Our in silico structural predictions suggest that $\mathrm{C} 3$ binds to $37 \mathrm{LR}$ in the laminin binding pocket and that this binding may be facilitated by a hydrogen bond between His 169 and the benzodioxin moiety of the compound. This hypothesis is supported by recent work highlighting a class of compounds from (or derived from) the NCI Diversity Set that were predicted to interact with the same general binding pocket, termed peptide $\mathrm{G}$, of 37 LR (161 to 180 aa) [60], albeit through hydrogen bonding with Gly 172 and a hydrophobic interaction with His 169. Of relevance, this binding region falls squarely within the known interaction region for PEDF and 37 LR (120 to 210 aa) [34]. Our in silico predictions were validated by an intrinsic tryptophan fluorescence assay employing Peptide G (161 to 180 aa), whereby titration of C3 decreased intrinsic tryptophan fluorescence in a dose dependent manner with an EC50 of $16.1 \mu \mathrm{M}$ while having 
no appreciable effect on tryptophan fluorescence in a same sequence scrambled peptide (Scramble G), suggesting that C3 binds specifically to the intrinsic fold of Peptide G. Taken together with the evidence that C3's potency (reduction in cell viability) is correlated with endogenous 37 LR levels, we suggest that C3 interacts with 37 LR.

Our lab and others have demonstrated that PEDF's potent antiangiogenic potential can be leveraged to treat both the tumor and the surrounding angiogenic microenvironment [39, 46-50]. While these gene delivery driven therapies show promise, we sought to identify small molecule that could recapitulate known signaling properties of PEDF but without the additional complications of peptide formulation, delivery of a recombinant protein, or gene delivery safety validation.
In our hands, we were unable to demonstrate a significant dose/response relationship between survival of PC-3 cells and increasing doses of recombinant PEDF (Supplementary Figure 3). This was not surprising to us as the anti-cancer/anti-angiogenic PEDF peptide $\mathrm{p} 18$ does not markedly alter PC-3 cell viability while still maintaining an in vivo potency [39], however, the result could also be due to variability inherent to PEDF preparations [70].

We investigated the expression of a panel of genes implicated in either proposed mechanisms for PEDF function or for $37 \mathrm{LR}$ function. Treatment of PC-3 cells with $50 \mu \mathrm{M}$ C3 for 48 hours markedly reduced transcription of VEGFR2 $(>-15$ fold change or FC), a known effect of PEDF treatment, previously shown to be mediated through a gamma secretase
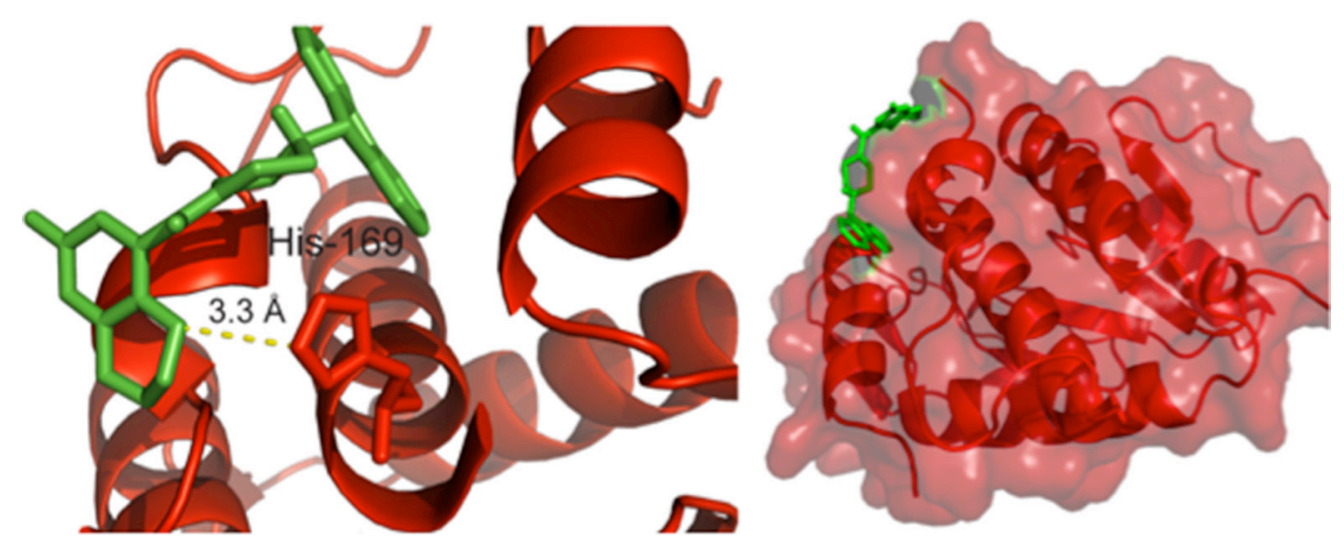

Figure 3: Redocking of hit compound C3. Redocking of C3 was performed as described in the methods and visualized using PyMol. Left, a pose depicting the most energetically favored positioning of C3 from the simulation featuring a $3.3 \AA$ hydrogen bond between the benzodioxin moiety and His 169. Right, the predicted binding pocket for C3 with the 37 LR crystal structure.

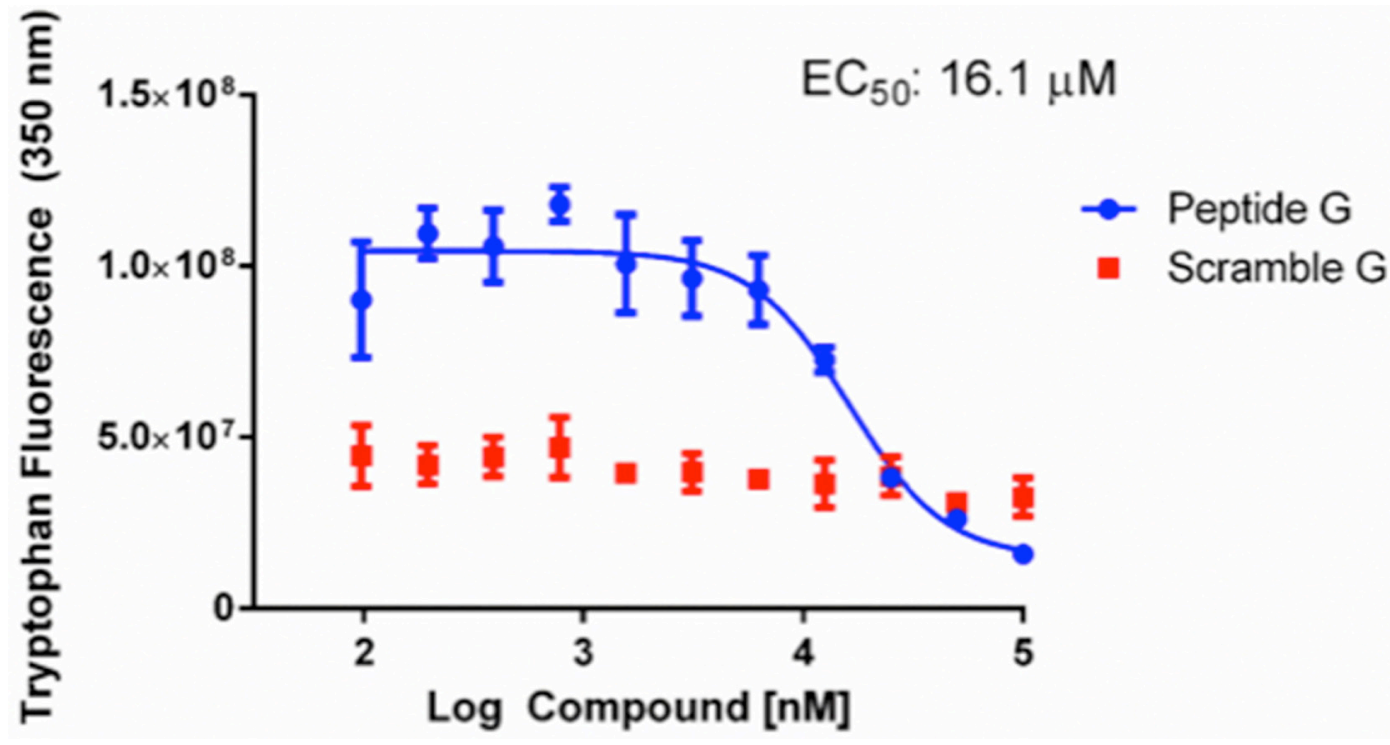

Figure 4: Reduction of tryptophan fluorescence by C3. $50 \mu \mathrm{M}$ Peptide G or Scramble G was incubated with concentrations of C3 ranging from $100 \mathrm{nM}$ to $100 \mu \mathrm{M}$. Intrinsic tryptophan fluorescence was quantified at $350 \mathrm{~nm}$ emission (270 nm excitation) and graphed as a function of $\mathrm{C} 3$ dose after subtracting baseline $\mathrm{C} 3$ fluorescence. GraphPad Prism was used to determine an EC50 for tryptophan reduction as described in the methods $(n=3 \pm \mathrm{SEM})$. 
dependent proteolysis of VEGFR2 [71]. A compensatory upregulation of VEGF was observed ( 4 FC) but with no concomitant upregulation of HIF1A. The known upregulation of MMP2 and MMP9 in response to PEDF treatment was also observed. However, where recombinant or endogenous full length PEDF protein is a substrate for proteolytic degradation [71] by MMP2 or MMP9, a small molecule that mimics PEDF should avoid such degradation, as the specific proteolytic sites are not present in C3. C3 also upregulated thrombospondin-1 (THBS1, $>10$ FC). THBS1, much like PEDF, has been implicated as a protein with dual anti-tumor and anti-angiogenic activity [72]. Additionally, the two proteins work in concert to downregulate angiogenesis [41]. Consistent with our finding that $\mathrm{C} 3$ did not alter cell viability via a caspase 3/7 dependent mechanism, we did not observe a significant upregulation of caspase 3 (CASP3) or BAX at the mRNA level. Overall, these results suggest that $\mathrm{C} 3$ could mimic PEDF responsive-genes or pathways in a manner consistent with an anti-angiogenic function.

While VEGF receptors have been demonstrated to be expressed by PC-3 cells and to facilitate an autocrine VEGF mediated signaling loop that may promote tumor growth [73], we wanted to orthogonally validate the $\mathrm{C} 3$-induced PEDF associated gene changes by testing the compound in an endothelial cell tube formation assay. 1, 10, and $50 \mu \mathrm{M}$ doses of $\mathrm{C} 3$ were able to completely or nearly completely inhibit endothelial tube formation, suggesting that C3's observed effects on angiogenesis-associated genes correlates with functional inhibition of angiogenesis.
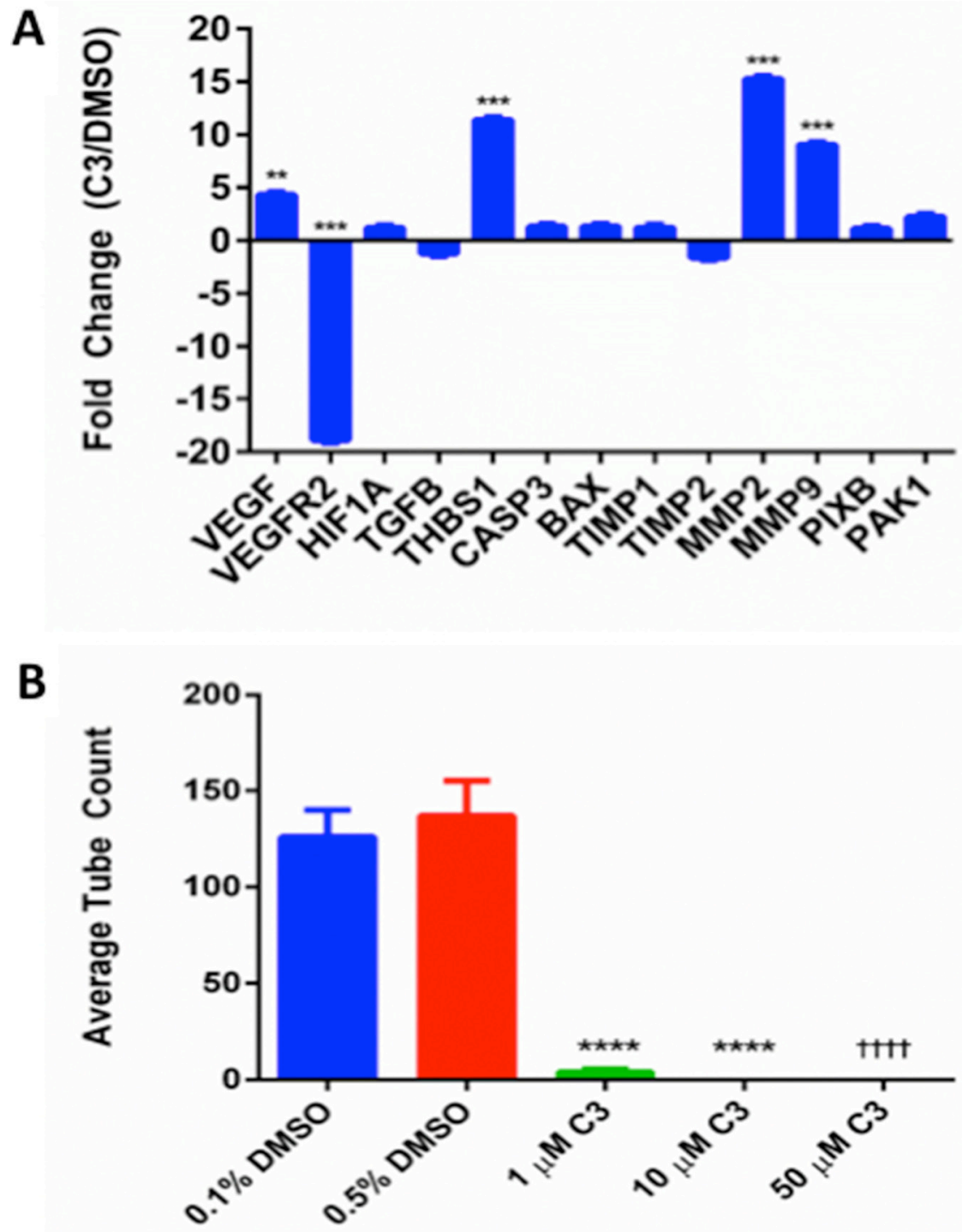

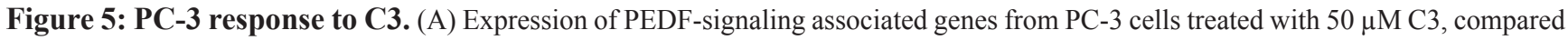
to DMSO control and normalized to GAPDH $(\mathrm{n}=3$, mean $\pm \mathrm{SEM})$. A Holm-Sidak multiple $\mathrm{t}$ test was used for statistical analysis $\left({ }^{*} p<0.05\right.$, $\left.{ }^{* *} p<0.01,{ }^{* * *} p<0.001\right)$. (B) Endothelial tube formation assay. Average tube count for $0.1 \%$ DMSO, $0.5 \%$ DMSO, and 1,10 , and $50 \mu \mathrm{M}$ treatment with $\mathrm{C} 3(n=7$, mean $\pm \mathrm{SEM}) .1$ and $10 \mu \mathrm{M} \mathrm{C} 3$ were compared with respective $0.5 \%$ DMSO (unpaired two-tailed t test, ${ }^{* * * *} p<$ 0.0001). $50 \mu \mathrm{M} \mathrm{C} 3$ was compared with respective 0.1\% DMSO (unpaired two-tailed t test ${ }^{\dagger \dagger} p<0.0001$ ). 

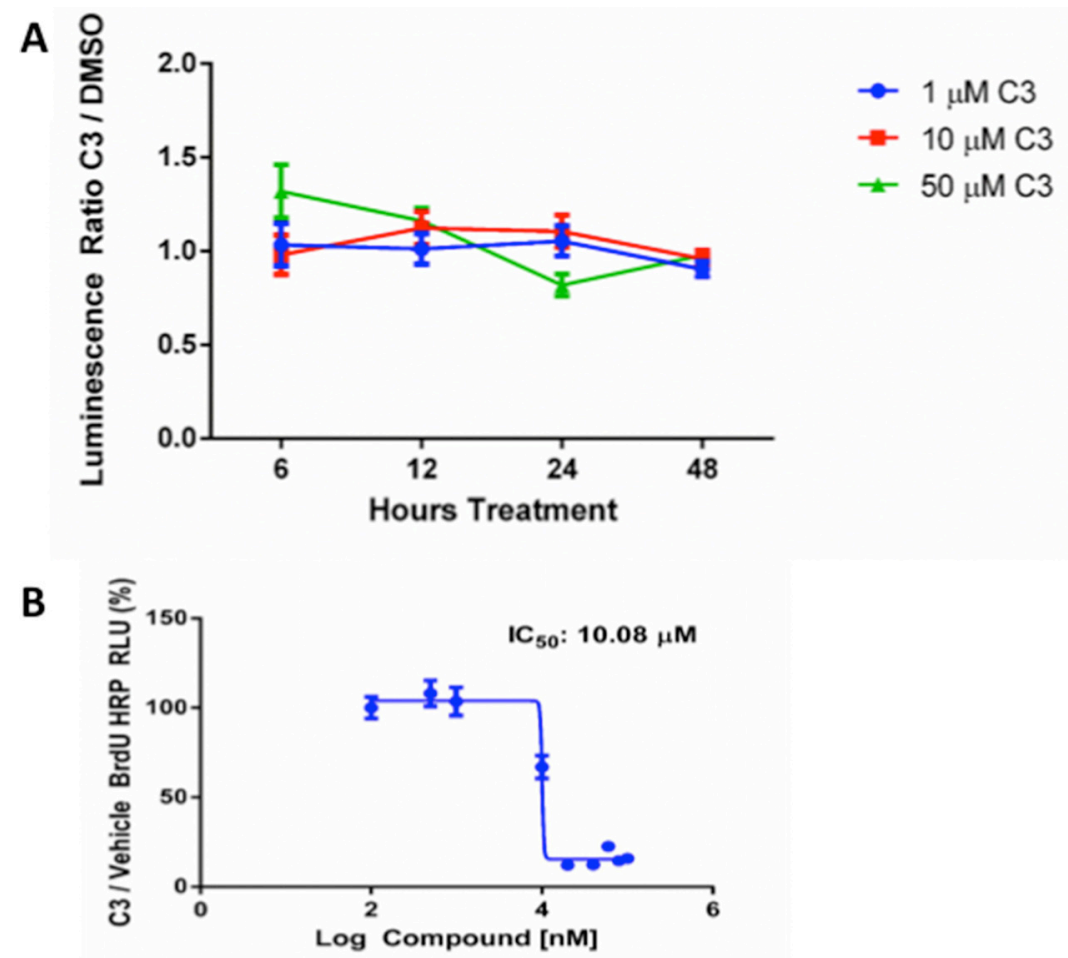

Figure 6: (A) Caspase 3/7 activation in response to C3 treatment. Average luminescence ratio (active caspase 3/7) for PC-3 cells treated with 1,10 , or $50 \mu \mathrm{M} \mathrm{C} 3$ for $6,12,24$, and 48 hours $(n=3$, mean \pm SEM) and normalized to DMSO control (results not significant, one-way ANOVA). (B) BrdU Incorporation in response to C3 treatment. PC-3 cells were treated with $100 \mathrm{nM}$ to $100 \mu \mathrm{M} \mathrm{C} 3$ for 24 hours and BrdU incorporation was quantified using HRP generated luminescence from an antibody pair recognizing $\operatorname{BrdU}(n=6, \mathrm{mean} \pm \mathrm{SEM})$. C3 BrdU signal was normalized to a row where PC-3 cells were exposed to $0.5 \%$ DMSO (assay conditions). Curve obtained using GraphPad Prism as described in the methods.

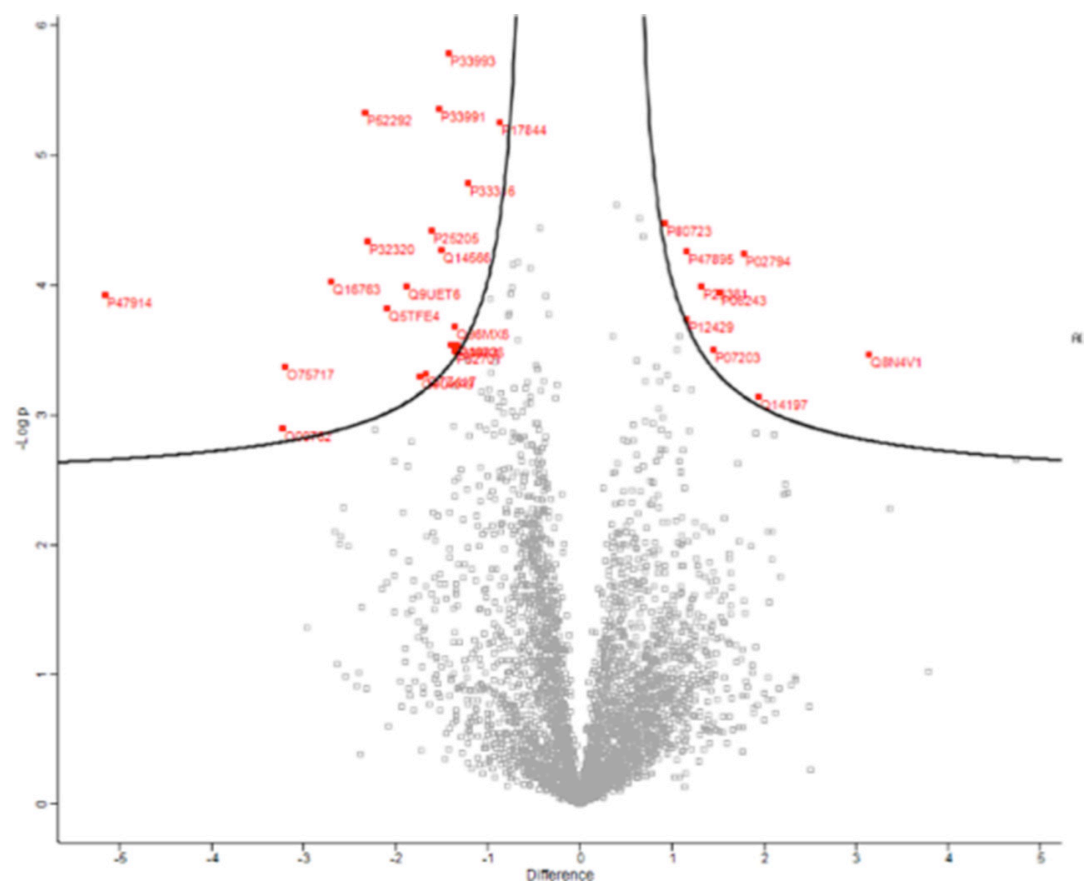

Figure 7: Volcano plot of differentially regulated proteins in response to C3 treatment. PC-3 cells were treated with DMSO or $10 \mu \mathrm{M} \mathrm{C} 3$ for 72 hours and proteins were quantified using label free quantitative mass spectrometry. Proteins were graphed by fold change (Difference) and significance (-Log p) using a false discovery rate of 0.05 and an S0 of 0.1 . Protein IDs in red were considered significantly up or down regulated using the Perseus software. 

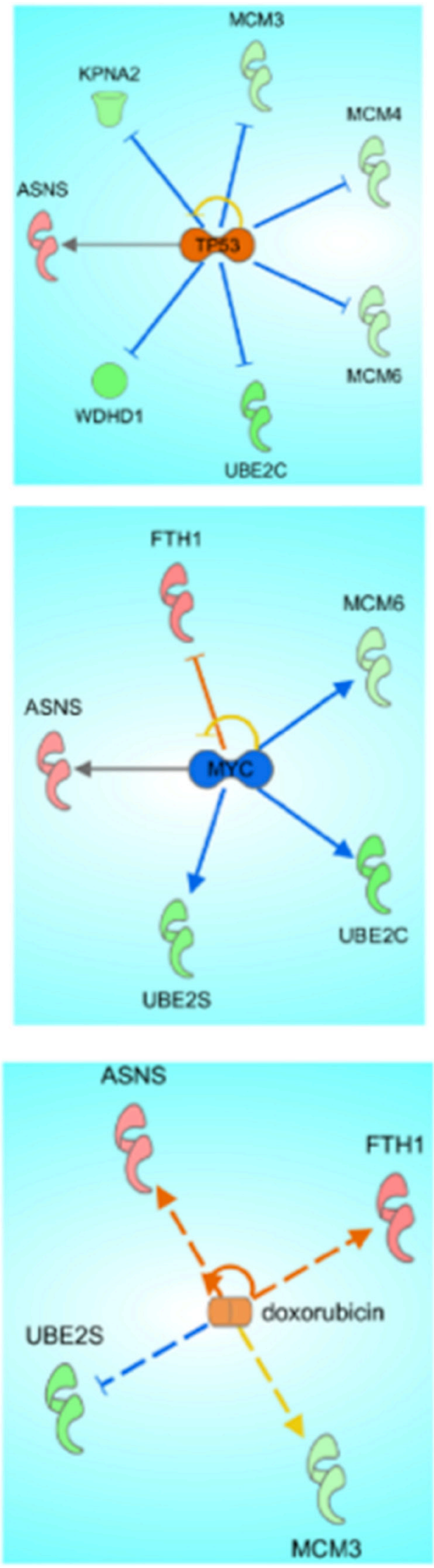

Figure 8: Ingenuity pathway analysis of proteomic data from C3 treatment of PC-3 cells. Significantly up and down regulated proteins were analyzed using Ingenuity Pathway Analysis Software and mapped to canonical pathways. 
Because the functions of $37 \mathrm{LR}$ and PEDF are diverse and the mechanisms underlying PEDF's antitumor properties are still unclear (in contrast with its wellcharacterized role in anti-angiogenesis), we employed an unbiased label-free quantitative mass spectrometry approach to determine the types and levels of proteins modulated in PC-3 cells following treatment with a moderate dose of $\mathrm{C} 3(10 \mu \mathrm{M})$, chosen from the BrdU and t-scratch functional assays. Our objective was to gain insight into the potential mechanisms of activity of $\mathrm{C} 3$ in PC-3 cells through proteomic analyses. The most downregulated protein (RPL29, $\log 2 \mathrm{FC}-5.2$ ), is a member of the $60 \mathrm{~S}$ ribosome which indicates that $\mathrm{C} 3$ may be acting to modify translational pathways, consistent with a hypothesis that C3 is exerting anti-tumor effects through 37 LR. Moreover, RPL29 binds and interacts with the extracellular matrix and knockdown of RPL29 has been reported to induce colon cancer cell differentiation [74]. siRNA knockdown of RPL29 in an aortic model of angiogenesis resulted in significantly decreased microvessel sprouting in response to VEGF stimulation [75]. These alterations might suggest a role for C3 in the regulation of angiogenesis through impacting regulation of translation.

Consistent with our observations that $\mathrm{C} 3$ inhibited cell viability, cell proliferation, and cell migration, we observed a downregulation of several MCM family proteins, MCM-3, MCM-4, and MCM-6. MCM proteins serve as a checkpoint for the S phase of the cell cycle and are considered diagnostic markers for poor prognosis in a variety of cancers [76-78]. Further evidence for disruption of DNA synthesis, as evidenced by C3's ability to inhibit BrdU incorporation, was confirmed by down regulation of the E2 ligases UBE2S and $\mathrm{UBE} 2 \mathrm{C}$, proteins required for mitotic exit [79, 80]. UBE2C is considered a potent oncogene and is highly upregulated in castration-resistant prostate cancer [81]. The mitotic/centromere associated protein WDHD1 was also downregulated [82]. C3 decreased levels of CDA, cytidine deaminase, an enzyme well characterized for its ability to decrease the efficacy of gemcitabine chemotherapy [83], suggesting that $\mathrm{C} 3$ could be explored in the future as a part of a combinatorial chemotherapeutic regimen. We also observed downregulation of KPNA2, an importin and a key marker of poor disease prognosis and metastatic prostate cancer aggressiveness [84]. In combination, these changes suggest a role for $\mathrm{C} 3$ in regulating cancer cell aggressiveness through regulation of mitotic/cell division machinery function.

C3 also upregulated GPX1, glutathione peroxidase 1, a response protein that facilitates sequestration of cytotoxic oxidants and a described putative tumor suppressor with loss of function in PC-3 cells [85]. Upregulation of FTH1, ferritin heavy chain 1, may be a compensatory response to C3's effects on angiogenic pathways, as FTH1 can reestablish tumor angiogenesis [86]. Upregulation of ASNS, asparagine synthetase, may also be a compensatory response, as ASNS

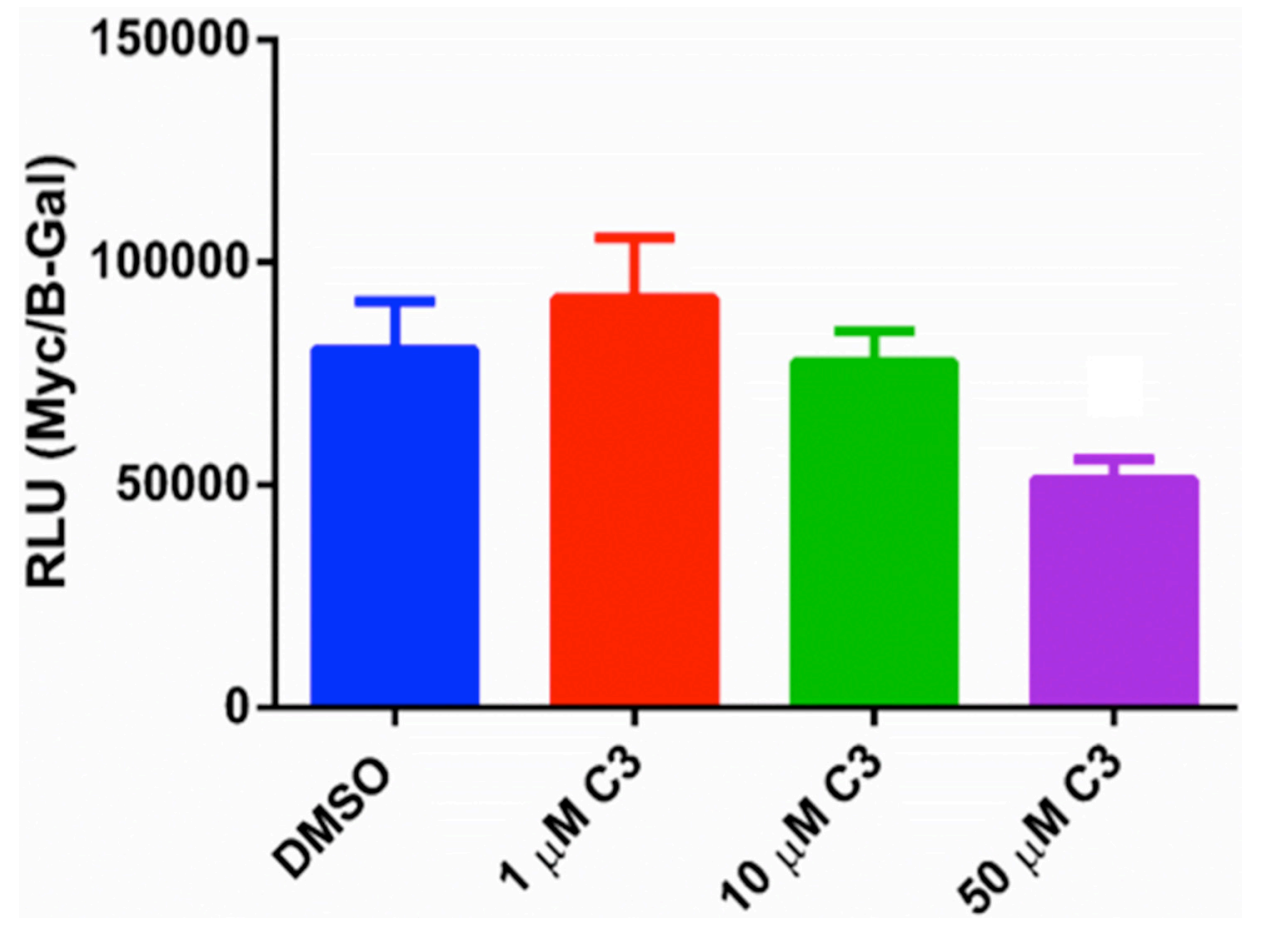

Figure 9: Luciferase promoter assay in PC-3 cells. PC-3 cells were treated with 1, 10, $50 \mu \mathrm{M} \mathrm{C} 3$ or DMSO control for 24 hours after a 24 transfection with Myc-Luc and a B-gal plasmid to normalize for transfection efficiency $(n=6$, mean \pm SEM). Relative light units calculated by normalizing Myc-Luc signal to B-gal signal. A one-way ANOVA was used for statistical analysis $(p<0.05)$. The linear trend was also significant (post test for linear trend, $p<0.05$ ). 
A
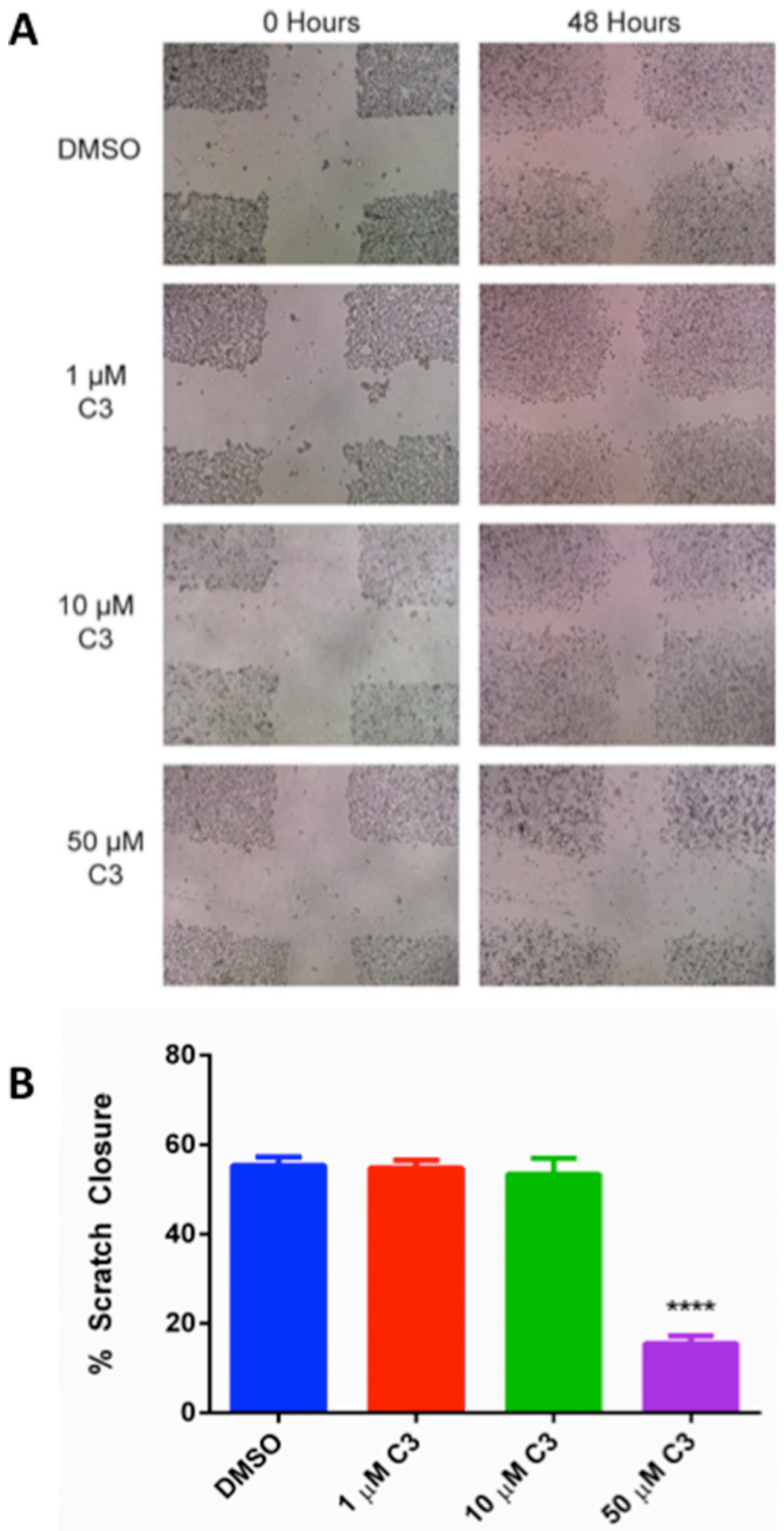

Figure 10: (A) Representative Scratch Assay brightfield images for PC-3 cells in response to C3 treatment. PC-3 cells were treated with 1, 10, $50 \mu \mathrm{M} \mathrm{C} 3$ or DMSO control after scratch formation and images were recorded using a brightfield microscope as described in the methods. (B) Quantification of Scratch Assay. Brightfield images were quantified using the t-scratch program and represented as $\%$ scratch closure after 48 hours of migration compared to a 0 hour control $(n=9$, mean \pm SEM). A one-way ANOVA test was used for statistical analysis $(p<0.05)$. A post-hoc Sidak's multiple comparisons test was also used $\left({ }^{* * * *} p<0.0001,50 \mu \mathrm{M}\right.$ C3 vs. DMSO, all other doses vs. DMSO were not significant). 
is upregulated under cellular stress conditions including the unfolded protein response or endoplasmic reticulum stress [87]. Consistent with the hypothesis that C3 may disrupt translation events, we noted an upregulation of ICT1, a peptidyl tRNA hydrolase that responds to mitoribosomal arrest [88], but the significance of this finding is unknown since ICT1 may be implicated in cancer progression [89].

While the majority of the proteins detected via mass spectrometry appeared to support the hypothesis that the net effect of $\mathrm{C} 3$ on PC-3 cells was an activation of antitumor signaling, we further analyzed the dataset using ingenuity pathway analysis to assess the effects of $\mathrm{C} 3$ en masse. Pathway analysis indicated a predicted activation of P53, a predicted inactivation of MYC, and suggested that the signature of proteins altered by $\mathrm{C} 3$ was consistent with the known effects of doxorubicin. Both activation of P53 and inactivation of MYC involved the MCM family of proteins detected in this study as well as UBE2S and/or UBE2C. We chose to orthogonally validate our proteomic data set and IPA interpretations using a luciferase reporter system for MYC binding elements, reasoning that PC-3 cells are functionally considered P53 null [90] and that advanced prostate cancers frequently overexpress c-myc [91]. $50 \mu \mathrm{M}$ C3 was able to significantly decrease c-myc binding activity in a reporter assay, validating our proteomic results.

Taken together, we propose that C3's phenotypic effects on PC-3 cells are a dual combination of antitumor/anti-growth pathway and anti-angiogenic pathway activation, of which there is some overlap. The dual antitumor/anti-angiogenesis activity is consistent with the described effects of PEDF reported by us and others. Given that $\mathrm{C} 3$ inhibits BrdU uptake, downregulates MCM family proteins, and downregulates c-myc activity, we propose that $\mathrm{C} 3$ is a bona fide anti-proliferative agent that warrants further pre-clinical investigation in the realm of prostate cancer drug discovery and development, and that 37 LR continues to be a promising avenue for targeted therapeutic intervention. We believe future efforts in the $37 \mathrm{LR}$ targeting field would benefit from development of a high throughput binding assay and we aim to test both $\mathrm{C} 3$ and derivatives of C3 in such a format, perhaps employing a tryptophan fluorescence assay using Peptide G. A peptide based highthroughput binding assay is economical and facilitates true structure activity relationships to be derived between Peptide G/37 LR and lead iterations of C3 or other 37 LR active compounds. Moreover, we plan to test the efficacy of C3 in a mouse model of prostate cancer prior to lead optimization.

\section{MATERIALS AND METHODS}

\section{In silico screening ligand \& protein preparation}

The $2.15 A$ crystal structure of 37 LR (PDB ID: $3 \mathrm{BCH}$ ) [92] was cleaned and prepared using AutoDock Vina and AutodockTools [93]. The Maybridge HitFinder ${ }^{\mathrm{TM}}$ version 10 library comprising 14,400 drug-like compounds was accessed using "Docking At UTMB" (now "Docking At TACC"), a virtual screening drug discovery web portal that performs automated docking of pre-cleaned .pdbqt libraries against an input structure [65]. The top 24 compounds $(-9.3 \mathrm{kcal} / \mathrm{mol}$ to $-7.9 \mathrm{kcal} / \mathrm{mol})$ were recorded and evaluated for downstream applications.

\section{Refinement of in silico hits}

The top 24 compounds as assessed by predicted binding scores via docking were evaluated for drug-likeness by a medicinal chemist. 7 final compounds were ordered and synthesized from Maybridge via ThermoFisher Scientific. Compounds were resuspended in $100 \%$ dimethylsulfoxide (DMSO, Sigma Aldrich) to $10 \mathrm{mM}$, vigorously mixed, inspected for absence of precipitates, and stored at $-20^{\circ} \mathrm{C}$ in amber tubes until use. Maybridge compound names, clogp, and nicknames are provided in Table 3.

\section{Cell culture conditions}

All cell lines were routinely passaged and maintained at $37^{\circ} \mathrm{C}$ with $5 \% \mathrm{CO}_{2}$. EA.hy926 endothelial cells (Endo, ATCC CRL-2922) were cultured in 10\% fetal bovine serum (FBS, ThermoFisher) with $1 \times$ Dulbecco's Modified Eagle Medium (DMEM, Corning) and $1 \times$ antibiotic-antimycotic (anti-anti, 100 units $/ \mathrm{mL}$ penicillin, $100 \mu \mathrm{g} / \mathrm{mL}$ streptomycin, and $0.25 \mu \mathrm{g} / \mathrm{mL}$ amphotericin B; Gibco). LNCaP prostate tumor cells (ATCC CRL-1740) were cultured in 10\% FBS (ATCC) with 1X RPMI-1640 (Corning) and $1 \times$ antianti. PC-3 prostate tumor cells (ATCC CRL-1435) were cultured in $10 \%$ FBS (ThermoFisher) with $1 \times$ RPMI1640 and $1 \times$ anti-anti. SH-SY5Y neuroblastoma cells (gift from Dr. Rakez Kayed) were cultured in 10\% FBS (ThermoFisher) with 1X Opti-MEM I (Gibco) and 1× antianti. Mouse TRAMP-C2 cells were obtained from ATCC and maintained in Dulbecco's Modified Eagle's Medium Nutrient Mixture F-12 (DMEM:F12; Corning) with 10\% FBS (ThermoFisher) and $1 \times$ anti-anti. TRAMP-C2 cells [94] were transduced with a lentivirus expressing activated H-rasG12V (Lv-Hras) [95] at a multiplicity of infection of 1 and a lentivirus expressing mouse androgen receptor (mAR) at a multiplicity of infection of 1, resulting in TC2-Ras. Their characterization is shown in Supplementary Figure 4. Cells were regularly passaged by trypsinization $(0.05 \%$ (v/v) trypsin, $0.53 \mathrm{mM}$ EDTA) or lifted using $20 \mathrm{mM}$ EDTA (Sigma) in $1 \mathrm{X}$ DPBS.

\section{Cell viability screen}

PC-3, Endo, TC2-Ras, SH-SY5Y, and LNCaP cells were seeded in 96-well plates at 1,500 cells per well using the Scepter cell counter (EMD Millipore). Cells were continuously incubated with compound using a 6-point dose curve: $100,57.5,32.4,18.6,10.5$, and $6.0 \mu \mathrm{M}$ in their respective complete media. Cell viability was measured 
Table 3: Selected compounds

\begin{tabular}{ccccc}
\hline Compound & Nickname & cLogP & MW (Da.) \\
\hline DP01026 & C1 & 6.1 & 389.496 \\
HTS07938 & C2 & 5.18 & 481.981 \\
HTS07944 & C3 & 4.53 & 430.477 \\
HTS08262 & C4 & 4.06 & 430.477 \\
HTS08762 & C5 & 6.1 & 430.477 \\
HTS10652 & C6 & 4.54 & 470.594 \\
RF02945 & C7 & 2.99 & 416.301 \\
\hline
\end{tabular}

by using the cell counting kit-8 (CCK-8, Dojindo). CCK-8 uses a highly water soluble tetrazolium salt, WST-8, which is reduced by dehydrogenase in cells to yield a yellow formazan dye, which is directly proportional to the number of living cells. CCK-8 absorbance was measured at $450 \mathrm{~nm}$ using a GloMax Multimode Reader (Promega). Readings were performed the day after seeding to normalize for variations in cell seeding and after 96 hours of compound treatment. After each reading, CCK-8 media was removed and replaced with media containing compound as described previously. A serial dilution using vehicle, dimethyl sulfoxide (DMSO), for each cell line was performed in parallel along with inclusion of a media only negative control and a cell only positive control.

\section{Cell viability screen statistics}

As described previously, an initial baseline CCK8 reading was performed at 24 hours post seeding to correct for variations in seeding density. First, $450 \mathrm{~nm}$ values for each well were subtracted from media only readings to correct for baseline absorbance. Then, the 96 hour readings were normalized to their respective 24 hour readings to control for seeding variation. Percent cell viability was obtained by dividing corrected 96 hour values by untreated cell only control readings, which were normalized to $100 \%$ on the y-axis. Average compound values were reported in triplicate and standard error of the mean (SEM) calculated per plate, with DMSO values reported in duplicate with SEM per plate. Since the compounds were designed to mimic PEDF, an inhibitor of $37 \mathrm{LR}$, we postulated that we could calculate $\mathrm{IC}_{50}$ values for each compound. $\mathrm{IC}_{50}$ represent the concentration of an inhibitor where the response is reduced by half. $\mathrm{IC}_{50} \mathrm{~s}$ were calculated using a nonlinear fit (log(inhibitor) vs. response - variable slope (four parameters)) in GraphPad Prism 6.

\section{Endogenous 37 LR expression levels in screened cell lines}

PC-3, Endo, TC2-Ras, SH-SY5Y, and LNCAP cells were grown in $100 \mathrm{~mm}$ plates in complete media and lifted at $\sim 90 \%$ confluency using $20 \mathrm{mM}$ EDTA in $1 \times$ DPBS. Cells were pelleted, media was aspirated, and pellets were frozen at $-80^{\circ} \mathrm{C}$ until required for analysis. Total protein was isolated using 1X RIPA buffer (Thermo Scientific) containing 1X Halt Protease Inhibitor (Thermo Scientific), $5 \mathrm{mM}$ EDTA, and Phosphatase Inhibitor Cocktails 2 and 3 (Sigma Aldrich). Cells were lysed passively on ice for thirty minutes, sheared using a tuberculin syringe (BD) and supernatant was separated from cellular debris after a 30 minute $14,000 \mathrm{rpm}$ spin at $4^{\circ} \mathrm{C}$. Protein concentration was determined using the BCA assay (Thermo Scientific). $50 \mu \mathrm{g}$ of protein was loaded onto a Bolt $4-12 \%$ BisTris Plus gel (Life Technologies) and electrophoresed for 30 minutes at $200 \mathrm{~V}$. Proteins were transferred onto nitrocellulose using the iBlot2 system (Life Technologies). The blot was blocked for 1 hour at room temperature using $5 \%$ BSA in $1 \mathrm{X}$ PBS with $0.1 \%$ Tween-20 (Acros). $37 \mathrm{LR}$ was probed using a rabbit polyclonal (Bioss, bs0900R, 1:250) and beta actin was probed using a mouse monoclonal (ThermoFisher, MA5-15739, 1:5000). Goat anti-rabbit IgG secondary (Licor, 925-68021, 1:15,000) and goat anti-mouse IgG secondary (Licor, 925-32210, $1: 15,000)$ were used to detect primary antibody and signal was detected using the Licor Odyssey CLx. Image Studio Lite (Licor, ver. 5.2) was used to quantify pixel intensity.

\section{Redocking and structural validation of hit compound C3}

Redocking of C3 was manually performed using Autodock Vina and AutodockTools with a $100 \AA$ \&ox with a center of $(13.8,52.9,39.2(\mathrm{x}, \mathrm{y}, \mathrm{z}))$ and an exhaustiveness of 1000. Pymol was used for visualization. C3 structure was confirmed using 1H-NMR, 13C-NMR, and HPLCMS-MS (data not shown).

\section{Intrinsic tryptophan fluorescence binding assay}

A 20-mer peptide encompassing the 37 LR binding site for laminin (aa 161-180) [61] was synthesized alongside a same-sequence 20-mer scramble peptide: IPCNNKGAHSVGLMWWMLAR (Peptide G), GGKMLWISVANNRLCMAPWH (Scramble G), at 98\% percent purity (United Biosystems). Dry peptides $(\sim 5 \mathrm{mg})$ were resuspended in $50 \mu \mathrm{L}$ of DMSO and diluted dropwise with $450 \mu \mathrm{L}$ of $\mathrm{dH}_{2} \mathrm{O}$. Final peptide 
concentration was determined via A280 using a Nanodrop by accounting for the molar absorptivity of the two tryptophans present in the peptides. For the binding assay, C3 was serially diluted from $100 \mu \mathrm{M}$ to $0.1 \mu \mathrm{M}$ in assay buffer (50 $\mu \mathrm{M}$ Peptide G or Scramble G, 1\% DMSO and $1 \times$ PBS) or in assay buffer containing no peptide using a 96 well black plate (BD Falcon). Using a SpectraMax i3 MultiMode instrument (Molecular Devices), spectra were collected in $1 \mathrm{~nm}$ increments from $300 \mathrm{~nm}$ to $460 \mathrm{~nm}$ using an excitation wavelength of $270 \mathrm{~nm}$. Tryptophan quenching was graphed as change in $350 \mathrm{~nm}$ fluorescence as a function of C3 concentration after subtracting baseline $\mathrm{C} 3$ fluorescence.

\section{BrdU incorporation assay}

PC-3 cells were seeded overnight in a white reflective 96 well plate (Costar) at 1,500 cells per well. Media was aspirated and cells were treated with $100 \mathrm{nM}$, $500 \mathrm{nM}, 1 \mu \mathrm{M}, 10 \mu \mathrm{M}, 20 \mu \mathrm{M}, 40 \mu \mathrm{M}, 60 \mu \mathrm{M}, 80 \mu \mathrm{M}$, or $100 \mu \mathrm{M} \mathrm{C} 3$ diluted in the previously described media with the addition of $0.5 \%$ DMSO. Compounds were incubated for 24 hours at $37^{\circ} \mathrm{C}$ with $5 \% \mathrm{CO} 2$ and assayed for BrdU incorporation using the manufacturer's kit and protocol (Cell Signaling Technology). Relative light units were quantified from Brd-U HRP using a GloMax MultiMode Reader. C3 signal was normalized to PC-3 cells exposed only to media with $0.5 \%$ DMSO. An $\mathrm{IC}_{50}$ was calculated as described.

\section{Apoptosis assay}

PC-3 cells were seeded overnight in white reflective 96 well plates at 15,000 cells per well. Media was aspirated and cells were treated for $6,12,24$, or 48 hours with $1 \mu \mathrm{M}, 10 \mu \mathrm{M}$, or $50 \mu \mathrm{M} \mathrm{C} 3$ diluted in the previously described media with the addition of $0.5 \%$ DMSO. Media was aspirated and cells were assayed for caspase 3/7 activity using a CaspaseGlo kit (Promega). Relative luciferase units were quantified using a GloMax MultiMode Reader.

\section{RT-qPCR}

PC-3 cells were seeded in 6 well plates at $3 \times 10^{5}$ cells per well and incubated with $50 \mu \mathrm{M}$ C3 or DMSO equivalent in $1 \times$ RPMI-1640, $1 \mathrm{X}$ anti-anti, and 2\% FBS (ThermoFisher) for 48 hours. PC-3 cells were lifted using $20 \mathrm{mM}$ EDTA in 1X DPBS and pelleted before isolating total RNA using the RNeasy Mini Kit (Qiagen). $1 \mu \mathrm{g}$ of RNA per sample was reverse transcribed using the amfiRivert cDNA synthesis master mix (GenDEPOT). Real-time PCR wells contained $1 \mu \mathrm{L}$ cDNA template, 2× SYBR Green Master Mix (Applied Biosystems), and $20 \mu \mathrm{M}$ forward and reverse primers. Primer sequences are provided in Table 4. qRT-PCR was performed on an
Eppendorf Realplex 2S (Eppendorf), using: $40 \times 95^{\circ} \mathrm{C}$ for 3 mins; $95^{\circ} \mathrm{C}$ for $3 \mathrm{~s} ; 60^{\circ} \mathrm{C}$ for $30 \mathrm{~s} ; 72^{\circ} \mathrm{C}$ for $8 \mathrm{~s}$ and analyzed using EP Realplex software (version 2.2). Fold changes were normalized to GAPDH using the ddCT method.

\section{Wound healing assay}

PC-3 cells were seeded in 6 well plates at 3 $\times 10^{5}$ cells per well in complete media until the cells reached confluency. Three horizontal and three vertical scratches were made in the confluent monolayers using a standard $200 \mu \mathrm{L}$ pipette tip and cellular debris were removed by washing with $1 \times$ DPBS three times. 1× RPMI-1640 supplemented with C3 or DMSO was added and cells were incubated for 48 hours as described previously. 0 hour and 48 hour images were acquired using a bright field microscope (VWR) and repositioning at 48 hours was achieved using $\mathrm{x}, \mathrm{y}$ stage coordinates after washing the monolayer three times with $1 \times$ DPBS to remove debris. Images were uploaded and analyzed for scratch geometry using the tscratch program [96]. First, global thresholding was performed, then individual images were manually inspected for single image threshold adjustment and scratch geometries were quantified.

\section{C3 dose experiment for proteomics}

PC-3 cells were seeded at $2.5 \times 10^{5}$ cells per well in six well plates in complete media and treated with $10 \mu \mathrm{M}$ C3 or $0.1 \%$ DMSO for 72 hours with a media change (also containing compound or vehicle) at the 48 hour mark. After 72 hours, cells were lifted using $20 \mathrm{mM}$ EDTA in $1 \mathrm{X}$ DPBS, pelleted, snap frozen in liquid nitrogen and stored at $-80^{\circ} \mathrm{C}$ until digested for mass spectrometry. A moderate $10 \mu \mathrm{M}$ dose was chosen from the BrdU and $\mathrm{t}$-scratch functional assays.

\section{Sample digestion}

Prior to digestion, cells were lysed using the Barocycler NEP2320 (Pressure Biosciences, Inc.). $50 \mu \mathrm{l}$ of $100 \mathrm{mM}$ ammonium bicarbonate was added to the cells, and they were lysed at $4^{\circ} \mathrm{C}$ under 35,000 psi for 45 minutes. $100 \mu \mathrm{g}$ of protein was isolated for digestion using an acetone precipitation. After removing acetone, samples were reduced and alkylated, and sequence grade Lys-C/Trypsin (Promega) was used to enzymatically digest the extracted protein. All digestions were carried out in the Barocycler NEP2320 at $50^{\circ} \mathrm{C}$ under 20,000 psi for 1 hour. Digested samples were cleaned over C18 spin columns (Nest Group) and dried. Resulting pellets were resuspended in $97 \%$ purified water $/ 3 \%$ acetonitrile $(\mathrm{ACN}) / 0.1 \%$ formic acid (FA). 


\begin{tabular}{|c|c|c|}
\hline Gene & Forward Primer $\left(5^{\prime}-3^{\prime}\right)$ & Reverse Primer $\left(5^{\prime}-3^{\prime}\right)$ \\
\hline$V E G F$ & CACTGAGGAGTCCAACATCACC & CTGCATTCACATTTGTTGTGC \\
\hline VEGFR2 & CCAGTCAGAGACCCACGTTT & AGTCTTTGCCATCCTGCTGA \\
\hline$H I F 1 A$ & AGTCAAGGGCATATCCTACAACA & CСTTATCAAGATGCGAACTCACA \\
\hline$T G F B$ & CCCGGGTTATGCTGGTTGA & AAGGACCTCGGCTGGAAGTG \\
\hline THBS1 & TGCTATCACAACGGAGTTCAGT & GCAGGACACCTTTTTGCAGATG \\
\hline$C A S P 3$ & ATGGAAGCGAATCAATGGAC & GGCTCAGAAGCACACAAACA \\
\hline$B A X$ & TCATGAAGACAGGGGCCTTTT & CAATCATCCTCTGCAGCTCCA \\
\hline TIMP1 & ACCACCTTATACCAGCGTTATGA & GGTGTAGACGAACCGGATGTC \\
\hline$T I M P 2$ & GCTGCGAGTGCAAGATCAC & TGGTGCCCGTTGATGTTCTTC \\
\hline$M M P 2$ & GTGCAGCTCTCATATTTGCCC & AAGAAGTATGGCTTCTGCCCTGAG \\
\hline$M M P 9$ & GGATGCCATTCACGTCGTCCTTAT & TGGGCTTAGATCATTCCTCAGTGC \\
\hline$P I X B$ & GTGTACCTCACGTATTGTGCC & CCGTGGTCAGCACGAGAAT \\
\hline$P A K 1$ & CAACTCGGGACGTGGCTAC & CAGTATTCCGGGTCAAAGCAT \\
\hline$G A P D H$ & ACAACTTTGGTATCGTGGAAGG & GCCATCACGCCACAGTTTC \\
\hline
\end{tabular}

\section{LC-MS}

The samples were analyzed using the Dionex UltiMate 3000 RSLC Nano System coupled to the Q Exactive $^{\mathrm{TM}}$ HF Hybrid Quadrupole-Orbitrap MS (Thermo Scientific). Peptides were loaded onto a trap column $(20 \mu \mathrm{m} \times 350 \mathrm{~mm})$ and washed using a flow rate of $5 \mu 1 /$ minute with $98 \%$ purified water $/ 2 \%$ ACN $/ 0.01 \%$ FA. The trap column was then switched in-line with the analytical column after 5 minutes. Peptides were separated using a reverse phase Acclaim PepMap RSLC C18 $(75 \mu \mathrm{m}$ $\times 15 \mathrm{~cm}$ ) analytical column using a 120 minute method at a flow rate of $300 \mathrm{nl} /$ minute. Mobile phase A consisted of $0.01 \% \mathrm{FA}$ in water and a mobile phase $\mathrm{B}$ consisted of $0.01 \% \mathrm{FA}$ in $80 \% \mathrm{ACN}$. The linear gradient started at $5 \% \mathrm{~B}$ and reached $30 \% \mathrm{~B}$ in 80 minutes, $45 \% \mathrm{~B}$ in 91 minutes, and $100 \%$ B in 93 minutes. The column was held at $100 \% \mathrm{~B}$ for the next 5 minutes before being brought back to 5\% B and held for 20 minutes. Sample was injected into the QE HF through the Nanospray Flex ${ }^{\mathrm{TM}}$ Ion Source fitted with an emission tip from Thermo Scientific. Data acquisition was performed monitoring the top 20 precursors at 120,000 resolution with an injection time of 100 milliseconds.

\section{Proteomics data processing}

Raw files obtained from the QExactive were uploaded using MaxQuant version 1.5.5.1 [97]. The following settings were applied in MaxQuant: Label free standard analysis using a multiplicity of 1 . Label free quantitation (LFQ) was performed using a minimum ratio count of 2 with fast LFQ. Peptides were re-quantified and matched. Digestion was set to trypsin and Lys-C using a max missed cleavage of 2 . The Orbitrap parameter was selected with a first search peptide tolerance of $20 \mathrm{ppm}$ and a main search peptide tolerance of $4.5 \mathrm{ppm}$. Individual peptide mass tolerances were turned on with a centroid match tolerance of $8 \mathrm{pm}$ and a centroid half width of $35 \mathrm{ppm}$. Calibration was intensity independent with a minimum peak length of 2 , a max charge of 7 , and a minimum score of 70 for recalibration. Oxidation of methionine and N-terminal acetylation were selected as variable modifications with a max of five modifications per peptide. Iodoethanol was selected as a fixed modification and contaminants were not excluded during the initial quantification. The minimum peptide length was set to 7 and the max peptide mass was set to $4600 \mathrm{Da}$. For unspecified searches, the minimum peptide length was set to 8 and the max peptide length was set to 25 . Unmodified unique and razor peptides were used for quantification. At the peptide match level, false discovery rate was set to 0.01 . Second peptides were included and match between runs was turned on with a match window time of 1 minute and an alignment window time of 20 minutes. Peptides were identified using an annotated human proteome fasta from the Uniprot database.

\section{Proteomics data analysis}

The identified protein groups generated by the MaxQuant program were uploaded to the Perseus program version 1.5.3.0 [98]. Site only, reverse, and contaminant peptides were removed from the dataset and missing values were imputed using a normal distribution. Invalid values were then excluded. Empty columns were removed. The volcano plot function was used to identify proteins that were significantly changed using a $t$-test with a false discovery rate of 0.05 and an $S_{0}$ of 0.1. A $1.5 \log 2$ fold cutoff change was applied for Ingenuity Pathway Analysis (IPA, Qiagen). 


\section{Angiogenesis tube formation assay}

EA.hy 926 cells were cultured as described earlier. $3 \times 10^{4}$ cells were seeded per well into a clear 96 well plate with $50 \mu \mathrm{L}$ of preformed matrigel media and treated with 1,10 , or $50 \mu \mathrm{M} \mathrm{C} 3$ or $0.1 \%$ or $0.5 \%$ DMSO in $1 \times$ DMEM, $10 \%$ FBS (ThermoFisher), and $1 \times$ antianti. Calcein was added following the manufacturer's protocols (Cellbiolab) and tube formation images were captured using an inverted fluorescence microscope (Olympus, IX71).

\section{c-MYC binding site luciferase reporter assay}

15,000 PC-3 cells were seeded per well in a white reflective 96 well plate and transfected next day using $200 \mathrm{ng}$ of a c-MYC binding site luciferase (pBVLuc wt MBS 1-4) reporter plasmid and $4 \mathrm{ng}$ of cytomegalovirus (CMV)-LacZ (B-Gal) plasmid for six hours using DMRIE-C transfection reagent according to manufacturer's instructions. pBV-Luc wt MBS1-4 was a gift from Bert Vogelstein (Addgene plasmid \# 16564). Transfection reagent was removed and replaced complete media for an additional 18 hours. Cells were then treated with 1,10 , or $50 \mu \mathrm{M}$ of $\mathrm{C} 3$ for 24 hours. Media was aspirated, $1 \times$ passive lysis buffer was added, and cells were freeze-thawed after being stored at $-80^{\circ} \mathrm{C}$. Luciferase activity detection was measured using the Luciferase Assay System (Promega) and a Glomax Discover luminometer (Promega).

\section{Statistics}

Statistical analysis was performed using GraphPad Prism 6. All assays were run in triplicate with values shown as the mean \pm SEM unless otherwise indicated. Student's $t$-test was used for pairwise comparisons and one-way ANOVA was used for group comparisons with significance set at $p<0.05$. In the case of multiple comparisons, the Holm-Sidak test was used or a false discovery rate was applied.

\section{Abbreviations}

LR, Laminin Receptor, PEDF, pigment epithelium derived factor, VEGF, vascular endothelial growth factor, THBS1, thrombospondin-1, matrix metalloproteinase (MMP)-2 and -9, vascular endothelial growth factor receptor 2 (VEGFR2), transforming growth factor beta (TGFB), tissue inhibitor of metalloproteinase 2 (TIMP2), caspase-3 (CASP3), bcl-2-associated x protein (BAX), Rho guanine nucleotide exchange factor 7 (PIXB) and PAK1 (P21 (RAC1) Activated Kinase 1). DMSO, dimethyl sulfoxide, CCK-8, cell counting assay-8, ATCC, American Type Culture Collection, NCI, National Cancer Institute.

\section{Authors' contributions}

CSU wrote the manuscript body, designed experiments, collected data, analyzed data, and prepared all figures. ADQ performed the initial in silico screen for compound identification. MFN assisted with the endothelial tube assay data collection and analyses. JJS contributed to the western blot data analysis and in manuscript writing. MLF participated in manuscript writing and final editing, assisted with the endothelial tube assay, and designed experiments.

\section{ACKNOWLEDGMENTS}

We would like to acknowledge the Bindley Proteomics Core and Thiago Sobreira for bioinformatics analyses.

\section{CONFLICTS OF INTEREST}

None.

\section{FUNDING}

We would like to acknowledge support from NIH grant 1R21CA153165 (MLF), a CTSI Core Facility Award (MLF and CSU), and support from the College of Veterinary Medicine and the Department of Basic Medical Sciences at Purdue University.

\section{REFERENCES}

1. Landowski TH, Dratz EA, Starkey JR. Studies of the structure of the metastasis-associated 67- KDa Lamininbinding protein - Fatty acid acylation and evidence supporting dimerization of the $32 \mathrm{KDa}$ gene product to form the mature protein. Biochemistry. 1995; 34:11276-11287.

2. Ardini E, Pesole G, Tagliabue E, Magnifico A, Castronovo V, Sobel ME, Colnaghi MI, Menard S. The 67-kDa laminin receptor originated from a ribosomal protein that acquired a dual function during evolution. Molecular Biology and Evolution. 1998; 15:1017-1025.

3. Buto S, Tagliabue E, Ardini E, Magnifico A, Ghirelli C, van den Brule F, Castronovo V, Colnaghi MI, Sobel ME, Menard S. Formation of the $67-\mathrm{kDa}$ laminin receptor by acylation of the precursor. Journal of Cellular Biochemistry. 1998; 69:244-251.

4. DiGiacomo V, Meruelo D. Looking into laminin receptor: critical discussion regarding the non-integrin $37 / 67-\mathrm{kDa}$ laminin receptor/RPSA protein. Biol Rev Camb Philos Soc. 2015; 91:288-310.

5. Digiacomo V, Gando IA, Venticinque L, Hurtado A, Meruelo D. The transition of the $37-\mathrm{kDa}$ laminin receptor (RPSA) to higher molecular weight species: SUMOylation or artifact? Cell Mol Biol Lett. 2015; 20:571-85. 
6. Christiansen L, Pedersen S. Cloning, restriction endonuclease mapping and post-transcriptional regulation of rpsA, the structural gene for ribosomal protein S1. Mol Gen Genet. 1981; 181:548-551.

7. Kitakawa M, Isono K. An amber mutation in the gene rpsA for ribosomal protein $\mathrm{S} 1$ in Escherichia coli. Mol Gen Genet. 1982; 185:445-447.

8. Tafforeau L, Zorbas C, Langhendries JL, Mullineux ST, Stamatopoulou V, Mullier R, Wacheul L, Lafontaine DL. The complexity of human ribosome biogenesis revealed by systematic nucleolar screening of Pre-rRNA processing factors. Mol Cell. 2013; 51:539-551.

9. Guerra-Rebollo M, Mateo F, Franke K, Huen MS, LopitzOtsoa F, Rodríguez MS, Plans V, Thomson TM. Nucleolar exit of RNF8 and BRCA1 in response to DNA damage. Exp Cell Res. 2012; 318:2365-2376.

10. Rao NC, Barsky SH, Terranova VP, Liotta LA. Isolation of a tumor cell Laminin Receptor. Biochemical and Biophysical Research Communications. 1983; 111:804-808.

11. Barsky SH, Rao CN, Hyams D, Liotta LA. Characterization of a Laminin Receptor from human breast carcinoma tissue. Breast Cancer Research and Treatment. 1984; 4:181-188.

12. Hand PH, Thor A, Schlom J, Rao CN, Liotta L. Expression of Laminin Receptor in normal and carcinomatous human tissues as defined by a monoclonal antibody. Cancer Research. 1985; 45:2713-2719.

13. Venticinque $\mathrm{L}$, Jamieson $\mathrm{KV}$, Meruelo D. Interactions between laminin receptor and the cytoskeleton during translation and cell motility. PLoS One. 2011; 6:e15895.

14. Gauczynski S, Peyrin JM, Haik S, Leucht C, Hundt C, Rieger R, Krasemann S, Deslys JP, Dormont D, Lasmezas CI, Weiss S. The $37-\mathrm{kDa} / 67-\mathrm{kDa}$ laminin receptor acts as the cell-surface receptor for the cellular prion protein. Embo Journal. 2001; 20:5863-5875.

15. Gauczynski S, Nikles D, El-Gogo S, Papy-Garcia D, Rey C, Alban S, Barritault D, Lasmezas CI, Weiss S. The $37-\mathrm{kDa} / 67-\mathrm{kDa}$ laminin receptor acts as a receptor for infectious prions and is inhibited by polysulfated glycanes. Journal of Infectious Diseases. 2006; 194:702-709.

16. Hundt C, Peyrin JM, Haik S, Gauczynski S, Leucht C, Rieger R, Riley ML, Deslys JP, Dormont D, Lasmezas CI, Weiss S. Identification of interaction domains of the prion protein with its $37-\mathrm{kDa} / 67-\mathrm{kDa}$ laminin receptor. Embo Journal. 2001; 20:5876-5886.

17. Massia SP, Rao SS, Hubbell JA. Covalently immobilized Laminin peptide TYR-ILE-GLY-SER-ARG (YIGSR) supports cell spreading and colocalization of the 67-kilodalton Laminin Receptor with Alpha-actinin and Vinculin. Journal of Biological Chemistry. 1993; 268:8053-8059.

18. Jamieson KV, Hubbard SR, Meruelo D. Structure-guided identification of a laminin binding site on the laminin receptor precursor. J Mol Biol. 2011; 405:24-32.

19. Timpl R, Rohde H, Robey PG, Rennard SI, Foidart JM, Martin GR. Laminin--a glycoprotein from basement membranes. J Biol Chem. 1979; 254:9933-9937.
20. Iwamoto Y, Robey FA, Graf J, Sasaki M, Kleinman HK, Yamada Y, Martin GR. YIGSR, a synthetic laminin pentapeptide, inhibits experimental metastasis formation. Science. 1987; 238:1132-1134.

21. Menard S, Castronovo V, Tagliabue E, Sobel ME. New insights into the metastasis-associated $67 \mathrm{kD}$ laminin receptor. Journal of Cellular Biochemistry. 1997; 67:155165.

22. Menard S, Tagliabue E, Colnaghi MI. The $67 \mathrm{kDa}$ laminin receptor as a prognostic factor in human cancer. Breast Cancer Research and Treatment. 1998; 52:137-145.

23. Scheiman J, Jamieson KV, Ziello J, Tseng JC, Meruelo D. Extraribosomal functions associated with the $\mathrm{C}$ terminus of the $37 / 67 \mathrm{kDa}$ laminin receptor are required for maintaining cell viability. Cell Death Dis. 2010; 1:e42.

24. Wang Y, Dong H, Xu M, Xin B, Niu W, Xu D, Zhao P, Zhang B, Li Z, Liu L. 37-kDa laminin receptor precursor promotes lung adenocarcinoma cell invasion and metastasis by epithelial-to-mesenchymal transition. Cancer Gene Ther. 2014; 21:150-157.

25. Vacca A, Ribatti D, Roncali L, Lospalluti M, Serio G, Carrel S, Dammacco F. Melanocyte tumor progression is associated with changes in angiogenesis and expression of the 67-kilodalton laminin receptor. Cancer. 1993; 72:455-461.

26. van den Brûle FA, Berchuck A, Bast RC, Liu FT, Gillet C, Sobel ME, Castronovo V. Differential expression of the $67-\mathrm{kD}$ laminin receptor and $31-\mathrm{kD}$ human laminin-binding protein in human ovarian carcinomas. Eur J Cancer. 1994; 30A:1096-1099.

27. van den Brule FA, Buicu C, Berchuck A, Bast RC, Deprez M, Liu FT, Cooper DN, Pieters C, Sobel ME, Castronovo V. Expression of the $67-\mathrm{kD}$ laminin receptor, galectin-1, and galectin-3 in advanced human uterine adenocarcinoma. Hum Pathol. 1996; 27:1185-1191.

28. Wang L, Zhang D, Yu Y, Guan H, Qiao C, Shang T. RNA interference-mediated silencing of laminin receptor 1 (LR1) suppresses migration and invasion and downregulates matrix metalloproteinase (MMP)-2 and MMP9 in trophoblast cells: implication in the pathogenesis of preeclampsia. J Mol Histol. 2013; 44:661-668.

29. Lu CL, Xu J, Yao HJ, Luo KL, Li JM, Wu T, Wu GZ. Inhibition of human $67-\mathrm{kDa}$ laminin receptor sensitizes multidrug resistance colon cancer cell line SW480 for apoptosis induction. Tumour Biol. 2016; 37:1319-1325.

30. Susantad T, Smith DR. siRNA-mediated silencing of the 37/67-kDa high affinity laminin receptor in Hep3B cells induces apoptosis. Cell Mol Biol Lett. 2008; 13:452-464.

31. Gloe T, Riedmayr S, Sohn HY, Pohl U. The 67-kDa lamininbinding protein is involved in shear stress-dependent endothelial nitric-oxide synthase expression. J Biol Chem. 1999; 274:15996-16002.

32. Stitt AW, McKenna D, Simpson DA, Gardiner TA, Harriott $\mathrm{P}$, Archer DB, Nelson J. The 67-kd laminin receptor is preferentially expressed by proliferating retinal vessels in a 
murine model of ischemic retinopathy. Am J Pathol. 1998; 152:1359-1365.

33. Weis SM, Cheresh DA. Tumor angiogenesis: molecular pathways and therapeutic targets. Nat Med. 2011; 17:13591370.

34. Bernard A, Gao-Li J, Franco CA, Bouceba T, Huet A, Li Z. Laminin receptor involvement in the anti-angiogenic activity of pigment epithelium-derived factor. J Biol Chem. 2009; 284:10480-10490.

35. Goliath R, Tombran-Tink J, Rodriquez IR, Chader G, Ramesar R, Greenberg J. The gene for PEDF, a retinal growth factor is a prime candidate for retinitis pigmentosa and is tightly linked to the RP13 locus on chromosome 17p13.3. Mol Vis. 1996; 2:5.

36. Tombran-Tink J, Pawar H, Swaroop A, Rodriguez I, Chader GJ. Localization of the gene for pigment epithelium-derived factor (PEDF) to chromosome 17p13.1 and expression in cultured human retinoblastoma cells. Genomics. 1994; 19:266-272.

37. Tombran-Tink J, Chader GG, Johnson LV. PEDF: a pigment epithelium-derived factor with potent neuronal differentiative activity. Exp Eye Res. 1991; 53:411-414.

38. Dawson DW, Volpert OV, Gillis P, Crawford SE, Xu H, Benedict W, Bouck NP. Pigment epithelium-derived factor: a potent inhibitor of angiogenesis. Science. 1999; 285:245248.

39. Mirochnik Y, Aurora A, Schulze-Hoepfner FT, Deabes A, Shifrin V, Beckmann R, Polsky C, Volpert OV. Short pigment epithelial-derived factor-derived peptide inhibits angiogenesis and tumor growth. Clin Cancer Res. 2009; 15:1655-1663.

40. Haurigot V, Villacampa P, Ribera A, Bosch A, Ramos D, Ruberte J, Bosch F. Long-term retinal PEDF overexpression prevents neovascularization in a murine adult model of retinopathy. PLoS One. 2012; 7:e41511.

41. Volpert OV, Zaichuk T, Zhou W, Reiher F, Ferguson TA, Stuart PM, Amin M, Bouck NP. Inducer-stimulated Fas targets activated endothelium for destruction by antiangiogenic thrombospondin-1 and pigment epitheliumderived factor. Nat Med. 2002; 8:349-357.

42. Takenaka K, Yamagishi S, Jinnouchi Y, Nakamura K, Matsui T, Imaizumi T. Pigment epithelium-derived factor (PEDF)-induced apoptosis and inhibition of vascular endothelial growth factor (VEGF) expression in MG63 human osteosarcoma cells. Life Sci. 2005; 77:3231-3241.

43. Feng CC, Wang PH, Ding Q, Guan M, Zhang YF, Jiang HW, Wen H, Wu Z. Expression of pigment epitheliumderived factor and tumor necrosis factor- $\alpha$ is correlated in bladder tumor and is related to tumor angiogenesis. Urol Oncol. 2013; 31:241-246.

44. Zhang L, Chen J, Ke Y, Mansel RE, Jiang WG. Expression of pigment epithelial derived factor is reduced in non-small cell lung cancer and is linked to clinical outcome. Int J Mol Med. 2006; 17:937-944.
45. Zhou D, Cheng SQ, Ji HF, Wang JS, Xu HT, Zhang GQ, Pang D. Evaluation of protein pigment epitheliumderived factor (PEDF) and microvessel density (MVD) as prognostic indicators in breast cancer. J Cancer Res Clin Oncol. 2010; 136:1719-1727.

46. Zolochevska O, Yu G, Gimble JM, Figueiredo ML. Pigment epithelial-derived factor and melanoma differentiation associated gene- 7 cytokine gene therapies delivered by adipose-derived stromal/mesenchymal stem cells are effective in reducing prostate cancer cell growth. Stem Cells Dev. 2012; 21:1112-1123.

47. Zolochevska O, Shearer J, Ellis J, Fokina V, Shah F, Gimble JM, Figueiredo ML. Human adipose-derived mesenchymal stromal cell pigment epithelium-derived factor cytotherapy modifies genetic and epigenetic profiles of prostate cancer cells. Cytotherapy. 2014; 16:346-356.

48. Campochiaro PA, Nguyen QD, Shah SM, Klein ML, Holz E, Frank RN, Saperstein DA, Gupta A, Stout JT, Macko J, DiBartolomeo R, Wei LL. Adenoviral vector-delivered pigment epithelium-derived factor for neovascular agerelated macular degeneration: results of a phase I clinical trial. Hum Gene Ther. 2006; 17:167-176.

49. Sanagi T, Yabe T, Yamada H. Adenoviral gene delivery of pigment epithelium-derived factor protects striatal neurons from quinolinic acid-induced excitotoxicity. J Neuropathol Exp Neurol. 2010; 69:224-233.

50. Mahtabifard A, Merritt RE, Yamada RE, Crystal RG, Korst RJ. In vivo gene transfer of pigment epithelium-derived factor inhibits tumor growth in syngeneic murine models of thoracic malignancies. J Thorac Cardiovasc Surg. 2003; 126:28-38.

51. Scheiman J, Tseng JC, Zheng Y, Meruelo D. Multiple functions of the 37/67-kd laminin receptor make it a suitable target for novel cancer gene therapy. Mol Ther. 2010; 18:63-74.

52. Umeda D, Tachibana H, Yamada K. Epigallocatechin-3O-gallate disrupts stress fibers and the contractile ring by reducing myosin regulatory light chain phosphorylation mediated through the target molecule $67 \mathrm{kDa}$ laminin receptor. Biochem Biophys Res Commun. 2005; 333:628635.

53. Umeda D, Yano S, Yamada K, Tachibana H. Green tea Polyphenol epigallocatechin-3-gallate signaling pathway through $67-\mathrm{kDa}$ laminin receptor. Journal of Biological Chemistry. 2008; 283:3050-3058.

54. Tachibana H, Koga K, Fujimura Y, Yamada K. A receptor for green tea polyphenol EGCG. Nature Structural \& Molecular Biology. 2004; 11:380-381.

55. Shammas MA, Neri P, Koley H, Batchu RB, Bertheau RC, Munshi V, Prabhala R, Fulciniti M, Tai YT, Treon SP, Goyal RK, Anderson KC, Munshi NC. Specific killing of multiple myeloma cells by (-)-epigallocatechin-3-gallate extracted from green tea: biologic activity and therapeutic implications. Blood. 2006; 108:2804-2810. 
56. Fujimura Y, Yamada K, Tachibana H. A lipid raft-associated $67 \mathrm{kDa}$ laminin receptor mediates suppressive effect of epigallocatechin-3-O-gallate on FcepsilonRI expression. Biochem Biophys Res Commun. 2005; 336:674-681.

57. Tsai LC, Hsieh HY, Lu KY, Wang SY, Mi FL. EGCG/ gelatin-doxorubicin gold nanoparticles enhance therapeutic efficacy of doxorubicin for prostate cancer treatment. Nanomedicine (Lond). 2016; 11:9-30.

58. Tsukamoto S, Huang Y, Umeda D, Yamada S, Yamashita S, Kumazoe M, Kim Y, Murata M, Yamada K, Tachibana H. 67-kDa laminin receptor-dependent protein phosphatase 2A (PP2A) activation elicits melanoma-specific antitumor activity overcoming drug resistance. J Biol Chem. 2014; 289:32671-32681.

59. Mocanu MM, Ganea C, Georgescu L, Váradi T, Shrestha D, Baran I, Katona E, Nagy P, Szöllősi J. Epigallocatechin 3-O-gallate induces $67 \mathrm{kDa}$ laminin receptor-mediated cell death accompanied by downregulation of ErbB proteins and altered lipid raft clustering in mammary and epidermoid carcinoma cells. J Nat Prod. 2014; 77:250-257.

60. Pesapane A, Di Giovanni C, Rossi FW, Alfano D, Formisano L, Ragno P, Selleri C, Montuori N, Lavecchia A. Discovery of new small molecules inhibiting $67 \mathrm{kDa}$ laminin receptor interaction with laminin and cancer cell invasion. Oncotarget. 2015; 6:18116-18133. https://doi. org/10.18632/oncotarget.4016.

61. Castronovo V, Taraboletti G, Sobel ME. Functional domains of the 67-KDa Laminin Receptor Precursor. Journal of Biological Chemistry. 1991; 266:20440-20446.

62. Hermeking H, Rago C, Schuhmacher M, Li Q, Barrett JF, Obaya AJ, O'Connell BC, Mateyak MK, Tam W, Kohlhuber F, Dang CV, Sedivy JM, Eick D, et al. Identification of CDK4 as a target of c-MYC. Proc Natl Acad Sci U S A. 2000; 97:2229-2234.

63. Liang CC, Park AY, Guan JL. In vitro scratch assay: a convenient and inexpensive method for analysis of cell migration in vitro. Nat Protoc. 2007; 2:329-333.

64. Leelananda SP, Lindert S. Computational methods in drug discovery. Beilstein J Org Chem. 2016; 12:2694-2718.

65. Viswanathan U, Tomlinson SM, Fonner JM, Mock SA, Watowich SJ. Identification of a novel inhibitor of dengue virus protease through use of a virtual screening drug discovery Web portal. J Chem Inf Model. 2014; 54:2816-2825.

66. Houghten RA, Ganno ML, McLaughlin JP, Dooley CT, Eans SO, Santos RG, LaVoi T, Nefzi A, Welmaker G, Giulianotti MA, Toll L. Direct Phenotypic Screening in Mice: Identification of Individual, Novel Antinociceptive Compounds from a Library of 734,821 Pyrrolidine Bispiperazines. ACS Comb Sci. 2016; 18:51-64.

67. Penta A, Franzblau S, Wan B, Murugesan S. Design, synthesis and evaluation of diarylpiperazine derivatives as potent anti-tubercular agents. Eur J Med Chem. 2015; 105:238-244.

68. Kumar CS, Chandru H, Sharada AC, Thimmegowda NR, Prasad SB, Kumar MK, Rangappa KS. Synthesis and evaluation of 1-benzhydryl-sulfonyl-piperazine derivatives as inhibitors of tumor growth and tumor angiogenesis of mouse ehrlich ascites tumor in vivo. Med Chem. 2008; 4:466-472.

69. Li YT, Wang JH, Pan CW, Meng FF, Chu XQ, Ding YH, Qu WZ, Li HY, Yang C, Zhang Q, Bai CG, Chen Y. Syntheses and biological evaluation of 1,2,3-triazole and 1,3,4-oxadiazole derivatives of imatinib. Bioorg Med Chem Lett. 2016; 26:1419-1427.

70. Subramanian P, Deshpande M, Locatelli-Hoops S, Moghaddam-Taaheri S, Gutierrez D, Fitzgerald DP, Guerrier S, Rapp M, Notario V, Becerra SP. Identification of pigment epithelium-derived factor protein forms with distinct activities on tumor cell lines. J Biomed Biotechnol. 2012; 2012:425907.

71. Ablonczy Z, Prakasam A, Fant J, Fauq A, Crosson C, Sambamurti K. Pigment epithelium-derived factor maintains retinal pigment epithelium function by inhibiting vascular endothelial growth factor-R2 signaling through gamma-secretase. J Biol Chem. 2009; 284:30177-30186.

72. Haviv F, Bradley MF, Kalvin DM, Schneider AJ, Davidson DJ, Majest SM, McKay LM, Haskell CJ, Bell RL, Nguyen B, Marsh KC, Surber BW, Uchic JT, et al. Thrombospondin-1 mimetic peptide inhibitors of angiogenesis and tumor growth: design, synthesis, and optimization of pharmacokinetics and biological activities. J Med Chem. 2005; 48:2838-2846.

73. Jackson MW, Roberts JS, Heckford SE, Ricciardelli C, Stahl J, Choong C, Horsfall DJ, Tilley WD. A potential autocrine role for vascular endothelial growth factor in prostate cancer. Cancer Res. 2002; 62:854-859.

74. Liu JJ, Huang BH, Zhang J, Carson DD, Hooi SC. Repression of HIP/RPL29 expression induces differentiation in colon cancer cells. J Cell Physiol. 2006; 207:287-292.

75. Jones DT, Lechertier T, Reynolds LE, Mitter R, Robinson SD, Kirn-Safran CB, Hodivala-Dilke KM. Endogenous ribosomal protein L29 (RPL29): a newly identified regulator of angiogenesis in mice. Dis Model Mech. 2013; 6:115-124.

76. Hua C, Zhao G, Li Y, Bie L. Minichromosome Maintenance (MCM) Family as potential diagnostic and prognostic tumor markers for human gliomas. BMC Cancer. 2014; 14:526.

77. Ishimi Y, Okayasu I, Kato C, Kwon HJ, Kimura H, Yamada $\mathrm{K}$, Song SY. Enhanced expression of Mcm proteins in cancer cells derived from uterine cervix. Eur J Biochem. 2003; 270:1089-1101.

78. Meng MV, Grossfeld GD, Williams GH, Dilworth S, Stoeber K, Mulley TW, Weinberg V, Carroll PR, Tlsty TD. Minichromosome maintenance protein 2 expression in prostate: characterization and association with outcome after therapy for cancer. Clin Cancer Res. 2001; 7:27122718.

79. Garnett MJ, Mansfeld J, Godwin C, Matsusaka T, Wu J, Russell P, Pines J, Venkitaraman AR. UBE2S elongates 
ubiquitin chains on $\mathrm{APC} / \mathrm{C}$ substrates to promote mitotic exit. Nat Cell Biol. 2009; 11:1363-1369.

80. Bavi P, Uddin S, Ahmed M, Jehan Z, Bu R, Abubaker J, Sultana M, Al-Sanea N, Abduljabbar A, Ashari LH, Alhomoud S, Al-Dayel F, Prabhakaran S, et al. Bortezomib stabilizes mitotic cyclins and prevents cell cycle progression via inhibition of UBE2C in colorectal carcinoma. Am J Pathol. 2011; 178:2109-2120.

81. Chen Z, Zhang C, Wu D, Chen H, Rorick A, Zhang X, Wang Q. Phospho-MED1-enhanced UBE2C locus looping drives castration-resistant prostate cancer growth. EMBO J. 2011; 30:2405-2419.

82. Hsieh CL, Lin CL, Liu H, Chang YJ, Shih CJ, Zhong CZ, Lee SC, Tan BC. WDHD1 modulates the posttranscriptional step of the centromeric silencing pathway. Nucleic Acids Res. 2011; 39:4048-4062.

83. Weizman N, Krelin Y, Shabtay-Orbach A, Amit M, Binenbaum Y, Wong RJ, Gil Z. Macrophages mediate gemcitabine resistance of pancreatic adenocarcinoma by upregulating cytidine deaminase. Oncogene. 2014; 33:3812-3819.

84. Mortezavi A, Hermanns T, Seifert HH, Baumgartner MK, Provenzano M, Sulser T, Burger M, Montani M, Ikenberg K, Hofstädter F, Hartmann A, Jaggi R, Moch H, et al. KPNA2 expression is an independent adverse predictor of biochemical recurrence after radical prostatectomy. Clin Cancer Res. 2011; 17:1111-1121.

85. Trzeciak AR, Nyaga SG, Jaruga P, Lohani A, Dizdaroglu M, Evans MK. Cellular repair of oxidatively induced DNA base lesions is defective in prostate cancer cell lines, PC-3 and DU-145. Carcinogenesis. 2004; 25:1359-1370.

86. Coffman LG, Parsonage D, D'Agostino R, Torti FM, Torti SV. Regulatory effects of ferritin on angiogenesis. Proc Natl Acad Sci U S A. 2009; 106:570-575.

87. Balasubramanian MN, Butterworth EA, Kilberg MS. Asparagine synthetase: regulation by cell stress and involvement in tumor biology. Am J Physiol Endocrinol Metab. 2013; 304:E789-799.

88. Akabane S, Ueda T, Nierhaus KH, Takeuchi N. Ribosome rescue and translation termination at non-standard stop codons by ICT1 in mammalian mitochondria. PLoS Genet. 2014; 10:e1004616.
89. Aleman MJ, DeYoung MP, Tress M, Keating P, Perry GW, Narayanan R. Inhibition of Single Minded 2 gene expression mediates tumor-selective apoptosis and differentiation in human colon cancer cells. Proc Natl Acad Sci U S A. 2005; 102:12765-12770.

90. Liu C, Zhu Y, Lou W, Nadiminty N, Chen X, Zhou Q, Shi XB, deVere White RW, Gao AC. Functional p53 determines docetaxel sensitivity in prostate cancer cells. Prostate. 2013; 73:418-427.

91. Buttyan R, Sawczuk IS, Benson MC, Siegal JD, Olsson CA. Enhanced expression of the c-myc protooncogene in highgrade human prostate cancers. Prostate. 1987; 11:327-337.

92. Jamieson KV, Wu J, Hubbard SR, Meruelo D. Crystal structure of the human laminin receptor precursor. J Biol Chem. 2008; 283:3002-3005.

93. Trott O, Olson AJ. AutoDock Vina: improving the speed and accuracy of docking with a new scoring function, efficient optimization, and multithreading. J Comput Chem. 2010; 31:455-461.

94. Foster BA, Gingrich JR, Kwon ED, Madias C, Greenberg NM. Characterization of prostatic epithelial cell lines derived from transgenic adenocarcinoma of the mouse prostate (TRAMP) model. Cancer Res. 1997; 57:33253330 .

95. Zolochevska O, Ellis J, Parelkar S, Chan-Seng D, Emrick T, Wei J, Patrikeev I, Motamedi M, Figueiredo ML. Interleukin-27 gene delivery for modifying malignant interactions between prostate tumor and bone. Hum Gene Ther. 2013; 24:970-981.

96. Gebäck T, Schulz MM, Koumoutsakos P, Detmar M. TScratch: a novel and simple software tool for automated analysis of monolayer wound healing assays. Biotechniques. 2009; 46:265-274.

97. Cox J, Mann M. MaxQuant enables high peptide identification rates, individualized p.p.b.-range mass accuracies and proteome-wide protein quantification. Nat Biotechnol. 2008; 26:1367-1372.

98. Tyanova S, Temu T, Sinitcyn P, Carlson A, Hein MY, Geiger T, Mann M, Cox J. The Perseus computational platform for comprehensive analysis of (prote)omics data. Nat Methods. 2016; 13:731-740. 